\title{
RELIKWIARZ ŚW. STANISŁAWA Z ROKU 1505 I INNE TEGO TYPU RELIKWIARZE W POLSCE
}

Skarbiec katedry krakowskiej zachował najcenniejszy w Polsce, obok zbiorów jasnogórskich, zespół zabytków złotnictwa ${ }^{1}$. Do przyjęcia takiej oceny skłania ilość, różnorodność, przede wszystkim zaś wysoki poziom artystyczny przechowywanych tam obiektów. Znaczną z nich liczbę stanowią dary królów i biskupów krakowskich, którzy nie szczędzili fundacji wawelskiej katedrze.

Darem królewskim jest również puszkowy relikwiarz na głowę św. Stanisława stanowiący przedmiot naszych rozważań (ryc. 1-3). Wielokrotnie wzmiankowany i opisywany nasuwa on nadal szereg problemów - dlatego też podjęliśmy jeszcze raz jego opracowanie w osobnej rozprawie. Celem jej będzie wskazanie jakie były domniemane początki reprezentowanego przez relikwiarz typu oraz jego kontynuacji i naśladownictw w wiekach od XVI do XIX.

\section{STAN BADAŃ I OPIS DZIEEA}

Relikwiarz św. Stanisława już wcześnie wspomniany był w literaturze (w rozumieniu wspomnienia partykuły Świętego) - przykładem Krakowskich kościołów opisanie [...] z r. 1603 oraz Klejnoty stołecznego miasta Krakowa [...] Piotra Hiacynta Pruszcza (kolejne wydania 1647, 1650, 1745, 1861), gdzie mowa jest o relikwiach świętego biskupa. W w. XIX jako okazałym zabytkiem przeszłości, zajęli się nim badacze starożytności i popularyzatorzy pamiątek polskiej kultury - Ambroży Grabowski w r. $1852^{2}$ oraz A. Przeździecki i E. Rastawiecki w latach $1855-1858^{3}$. Szcze-

1 Część z nich jest obecnie eksponowana w Muzeum Katedralnym urządzonym w r. 1978.

2 A. Grabowski, Starożytnicze wiadomości o Krakowie, Kraków 1852, s. 291. W niniejszej rozprawie nie zajmuję się wzmiankami i opisami archiwalnymi relikwiarza, jak też różnymi puszkami na relikwie świętych, ze względu na ukierunkowany temat rozprawy.

3 A. Przeździecki, E. Rastawiecki, Wzory sztuki sredniowiecznej, seria 2, Warszawa $1855-1858$. 
gólną uwagę poświęcił puszce na głowę św. Stanisława monografista skarbców w katedrze krakowskiej i gnieźnieńskiej ks. Ignacy Polkowski, którego zasługą było rozpowszechnienie wiadomości o odkrytej wewnątrz relikwiarza sygnaturze wykonawcy, krakowskiego złotnika Marcina Marcińca ${ }^{4}$. Odtąd też relikwiarz będzie stale omawiany przy okazji charakteryzowania dorobku nadwornego złotnika królewskiego. Naturalnie zainteresował się dziełem Marcińca Leonard Lepszy, z historyków sztuki bliżej zajęli się puszką na głowę św. Stanisława Adam Bochnak i Julian Pagaczewski w związku z opracowywaniem mecenatu artystycznego kardynała Fryderyka Jagiellończyka w zakresie złotnictwa i opracowywania polskiego rzemiosła artystycznego wieków średnich ${ }^{5}$. Autorzy ci po raz pierwszy związali z Marcinem Marcińcem inne dzieła i wskazali, iż typ reprezentowany przez relikwiarz trwał w Polsce od wieku XVI aż do XIX włącznie, stanowiąc oryginalne rozwiązanie lokalnego złotnictwa. Należy jeszcze dodać, że pewnym cofnięciem się w dziedzinie badań był artykuł Bogusława Kopydłowskiego ${ }^{6}$, który niesłusznie przypisał Marcinowi Marcińcowi jak wykazał później Adam Bochnak — dalsze dzieła, zaś Tadeusz Dobrowolski w pracy o życiu artystów w czasach późnego gotyku skrupulatnie zebrał dane dotyczące twórcy relikwiarza, odtwarzając curriculum vitae mistrza ${ }^{7}$. Wreszcie autor niniejszej rozprawy opracował dla Polskiego słownika biograficznego obszerny życiorys Marcińca przy wykorzystaniu pełnej literatury przedmiotu ${ }^{8}$. Niepublikowaną pozostaje natomiast praca ks. A. Boksińskiego, dotycząca mecenatu artystycznego królowej Elżbiety, żony Kazimierza Jagiellończyka ${ }^{9}$.

Jak wynika z powyższego o relikwiarzu św. Stanisława sporo pisano, ustalony został autor puszki, typ jaki reprezentuje, brak natomiast wyczerpującego, monograficznego opracowania tego wybitnego dzieła sztuki. Zanim jednak zajmiemy się jego twórcą i naśladownictwami dzieła, sfor-

${ }_{4}^{4}$ I. Polkowski, Skarbiec katedralny na Wawelu, Kraków 1882, s. 17 nlb. (tekst na odwrociu tablicy z litografią relikwiarza).

5 A. Bochnak, J. Pagaczewski, Zabytki złotnictwa póznogotyckiego zwiazane $z$ kardynałem Fryderykiem Jagiellończykiem, „Prace Komisji Historii Sztuki" 9 (1948) s. $1-21$, rys. 1-17; ciż sami, Polskie rzemiosło artystyczne wieków średnich, Kraków 1959, s. 126-129, 130-136, 140-145, 253, 256. Istnieje także możliwość (zwrócił mi na to uwagę dr Jerzy Pietrusiński), iż prace związane przez powyższych uczonych w przekonywający sposób z osobą Marcina Marcińca mogą być dziełami jego ojca.

6 B. Kopydłow ski, Marcin Marciniec, złotnik krakowski, „Biuletyn Historii Sztuki" 16 (1954) $\mathrm{nr} 2$.

7 T. Dobrowolski, Życie, twórczość i znaczenie społeczne artystów polskich $i$ w Polsce pracujących w okresie późnego gotyku (1440-1520), Wrocław-Warszawa-Kraków 1965, s. 22, 59, 115-117.

8 J. Samek, Marciniec Marcin, [w:] Polski stownik biograficzny, t. 19 s. $586-587$.

${ }^{9}$ Natomiast publikacja M. Rożka: Skarbiec katedry na Wawelu (Kraków 1981) nie wnosi do tematu nic nowego. 
mułować należy konieczny dla dalszych rozważań krótki opis i analizę obiektu.

Relikwiarz na głowę św. Stanisława, biskupa i męczennika, wykonany został ze złota wysokiej próby, przy użyciu techniki lania, trybowania i grawerunku, wyjątkowo staranną cyzelerką, z zastosowaniem szlachetnych kamieni i pereł. Posiada on kształt ośmiobocznej puszki przykrytej spłaszczoną, otwieraną kopułką na zawiasach. Podstawę relikwiarza stanowią cztery posążki klęczących na niewielkich cokolikach aniołów, które trzymają ryte tarcze z herbami Polski, Litwy, kardynała Fryderyka Jagiellończyka i królowej Elżbiety (Habsburgów). Sama puszka relikwiarzowa posiada wydatny, profilowany cokół, wypełniony plastycznym fryzem roślinnym. Za pomocą większych pęków suchej roślinności zaakcentowano narożniki cokołu. Poszczególne ścianki puszki, posiadające kształt niskich, stojących prostokątów akcentują na narożnikach wątłe szkarpy, zwieńczone wygiętymi pilastrami.

W polach między szkarpami, posługując się rzeźbą, płaskorzeźbą i reliefem przedstawił złotnik najważniejsze sceny z życia, a właściwie męczeństwa świętego. Są to: Kupno wsi, Wskrzeszenie rycerza Piotra, Swiadczenie przed królem, Zabójstwo świętego, Rozsiekanie zwłok męczennika, Strzeżenie zwłok przez orły, Pogrzeb, Kanonizacja w Asyżu. W poszczególnych wydarzeniach bierze udział na ogół niewielka ilość postaci (dwie do siedmiu), co sprawia, że sceny są zrozumiałe i czytelne. Autor płaskorzeźb niewiele uwagi poświęcił przyrodzie, architekturze i realiom, które służą tylko do zaznaczenia, gdzie miało miejsce wydarzenie. Postacie dość krępe, o dużych głowach, z wyrazistymi twarzami przedstawione są często w skomplikowanych ruchach, przy słabym zainteresowaniu złotnika sprawami anatomii, a co za tym idzie prawidłowością tych ruchów. Gesty natomiast są wymowne i wraz ze zróżnicowanymi twarzami dobrze służą epickiemu charakterowi scen.

Wydaje się, że złotnik w równym stopniu zwracał uwagę na figuralną, jak i architektoniczną i roślinną dekorację relikwiarza. Swiadczy o tym fakt, że sceny są w górnej części, w dwóch trzecich wysokości, ograniczone przez wsparte na cienkich kolumienkach okazałe, silne plastycznie baldachimy złożone $\mathrm{z}$ motywów maswerkowych przechodzących $\mathrm{w}$ opatrzone kwiatonami, łukowate powyginane pinakle. Dochodzą one aż pod profilowany gzyms, wieńczący ścianki relikwiarza, którego narożniki, tak jak na cokole, zaakcentowane zostały za pomocą silnie zwiniętych, plastycznych liści. Podzielone listwami na osiem pól wieko relikwiarza z wziernikiem pośrodku posiada bardzo okazałą dekorację z kamieni szlachetnych i pereł, pośród których, obok szafirów, wyróżnia się czarny diament.

Umieszczony na relikwiarzu majuskułowy napis wyjaśnia, że $\mathrm{w} r$. 1505 ufundowała go katedrze krakowskiej z przeznaczeniem na głowę 
św. Stanisława biskupa królowa Elżbieta Rakuszanka, wdowa po królu Kazimierzu Jagiellończyku, z funduszy pozostałych po jej synach: Janie Olbrachcie i kardynale Fryderyku Jagiellończyku, staraniem biskupa krakowskiego Jana Konarskiego. Napis wewnątrz puszki: MARTINUS MARCZINECZ AVTHOR HVIVS OPERIS, informuje o wykonawcy dzieła.

Analizujący artystyczne walory relikwiarza roboty mistrza Marcińca stwierdzić należy, że aczkolwiek, jak już zaznaczono, nie był on biegłym odtwórcą postaci ludzkiej, relikwiarz odznacza się doskonałą robotą złotniczą i jest, co należy podkreślić, najbogatszym, jeśli chodzi o materiał i kameryzację, dziełem późnogotyckiego złotnictwa krakowskiego. $\mathrm{Na}$ wrażenie bogactwa składają się w równej mierze intensywny kolor złota wysokiej próby i wielobarwna kameryzacja, której dodają blasku perły. Wrażenie to potęguje jeszcze cechujący relikwiarz swoisty horror vacui, wyrażający się w pokryciu każdej jego płaszczyzny dekoracją figuralną, architektoniczną, roślinną lub kameryzacją. Zaznaczyć przy tym należy, że dzieło posiada wyważone, dość lekkie - w wyniku znacznego rozczłonkowania - proporcje; sceny figuralne zręcznie wkomponowano w pola bez reszty je wypełniając, logicznie zaś rozmieszczona dekoracja z jednej strony podkreśla najważniejsze elementy relikwiarza (są nimi zaakcentowane baldachimami sceny z życia świętego), a z drugiej wydobywa jego geometryczną budowę. Znakomite to dzieło sztuki zmusza do bliższego zapoznania się z osobowością jego autora, mistrza Marcina Marcińca, fundacja bowiem (właściwie zbiorowa) omówiona już została w osobnej pracy, poświęconej mecenatowi Elżbiety Rakuszanki.

\section{II}

\section{ŻYCIE I PRACE MARCINA MARCINCA}

Marcin Marciniec ${ }^{10}$, występujący w archwaliach także pod nazwiskiem Marcinkowicz i Marcinek, pochodził z zamożnej rodziny mieszczańskiej osiadłej w Krakowie, która występuje w aktach już od początku w. XV i wydała kilku wybitnych złotników. Ojcem Marcińca był złotnik o tym samym imieniu, zmarły około r. 1482. Zachowała się wzmianka archiwalna, że po śmierci ojca, wraz z matką Katarzyną, zwrócił Marciniec katedrze na Wawelu w Krakowie srebrne ampułki pobrane do przelania. Wzmianka

10 Rozdział niniejszy opracowany głównie na podstawie materiałów zebranych do cytowanego wyżej (przypis 8) hasła w PSB, gdzie podano najważniejszą literaturę przedmiotu. Najwięcej danych do życiorysu Marcina podają: D o brow ols k i, jw., s. 22, 59, 115-117; L. L e pszy, Przemyst złotniczy w Polsce, Kraków 1933, s. 135, (poz. 199); A. Bochnak, Mecenat Zygmunta Starego $w$ zakresie rzemiosła artystycznego, „Studia do dziejów Wawelu” 2 (1959), s. 133-135, 138-139, $226,239-242,259$. 
ta świadczy o tym, że ojciec Marcińca pracował na rzecz krakowskiej katedry, zapewne na zlecenie biskupa lub kapituły. W r. 1486 Marciniec czynny był już jako mistrz i przyjmował uczniów, z czego wnioskować można, że urodził się niedługo po połowie XV stulecia. Mniej chwalebną jest wzmianka z r. 1489, kiedy to skazany został on przez korporację na zapłacenie kary 25 grzywien srebra za pobicie towarzysza cechowego Ludwika ze Spiry. Zatarg ten nie przeszkodził mu pełnić w rok później (1490), a także w latach 1499 i 1507 najwyższej funkcji w korporacji — prymasa, to jest starszego stowarzyszenia. W r. 1494 występował Marciniec jako świadek testamentu innego złotnika - Pawła. Zachowały się też archiwalne informacje, iż Marciniec ożenił się w tym czasie z Elżbietą, z domu Neuberger, i miał z nią córkę Annę, zmarłą przed r. 1517. Z początku w. XVI posiadamy wzmianki o pracy Marcinca dla Jakuba Sancygniowskiego, starosty buskiego. Wiadomo też, że w latach 1493-1503 wykonywał zamówienia kard. Fryderyka Jagiellończyka. Dalsze koleje losu mistrza Miarcina uwarunkował fakt, że od r. 1502 pozostawał on na usługach królewicza, później króla Zygmunta I Starego. Około r. 1500, co znalazło swój wyraz w wykonaniu relikwiarza św. Stanisława, pracował też dla królowej Elżbiety Rakuszanki. O pozycji Marcińca wśród patrycjatu miejskiego Krakowa świadczy fakt, iż w r. 1513 wybrany został rajcą miejskim.

Zachowało się sporo informacji o uczniach Marcina Marcińca. Znamy ich ponad dwudziestu, choć Marciniec pobierał za naukę wysokie opłaty. Miẹdzy innymi uczył się u mistrza Marcina syn jego brata Stanisława Andrzej, o którym zachowało się sporo wiadomości. Od r. 1532 był Andrzej nadwornym złotnikiem króla Zygmunta I Starego, pracował też dla Bony Sforzy. Prace jego znamy tylko ze wzmianek archiwalnych, według których wiadomo, że w r. 1536 wykonał on złoty łańcuch dla Mikołaja Oporowskiego, kasztelana przemyskiego. Jest on być może również autorem pary srebrnych kandelabrów, wymienionych w testamencie bpa Piotra Tomickiego z r. 1539. Uczniem Marcińca był także syn złotnika krakowskiego Mikołaja Sachsa.

Przyczyną śmierci mistrza Marcińca, która nastąpiła po z górą trzydziestu latach działalności w Krakowie dnia 27 marca 1518 r., była febra. Należy jeszcze dodać, że niedługo przed śmiercią (18 VIII 1517) sporządził Marciniec zachowany do naszych czasów testament, w którym rozporządził pozostawionym po sobie znacznym majątkiem. Godną uwagi jest informacja, że po śmierci zmarłego, została wygłoszona przez pisarza miejskiego specjalna Pochwała, która, jak i testament oraz wcześniejsze wzmianki archiwalne, stanowi cenne źródło dla naszkicowania wizerunku tego wybitnego złotnika. Znani są także bracia mistrza Marcina, czynni również w Krakowie jako złotnicy - Jakub i Stanisław. Jakub pracował 
w latach 1487-1521, był starszym korporacji w r. 1513, posiadał też wielu uczniów. Stanisław, zapewne starszy brat Marcina, wzmiankowany w latach 1464 (?) - 1521, prymas korporacji w latach 1491, 1498 i 1513, wykształcił, jak mówią archiwalia, piętnastu uczniów, w rzeczywistości zapewne większa ich liczba przewinęła się przez jego warsztat.

Prace mistrza Marcina Marcinca znamy przede wszystkim z archiwaliów. Warto je jednak przytoczyć, albowiem informują one, jakich zleceń podejmował się złotnik. W r. 1501 na zamówienie wspomnianego już Jakuba Sancygniowskiego wykonał trzynaście srebrnych łyżek, które następnie - zleceniodawca bowiem ich nie odebrał - zmuszony był spieniężyć. Od r. 1502, pozostając na usługach królewicza Zygmunta Jagiellończyka, wykonywał różnego rodzaju wyroby złotnicze, a także naprawiał srebrne naczynia, skrzyneczki i klejnoty. W r. 1502 wykonał Marcin Marciniec na zamówienie królewicza Zygmunta złoty kielich do kościoła parafialnego w Olsztynie koło Częstochowy. W tymże roku, na to samo zamówienie wykonał dwa złote kielichy. Z kolei można wymienić kielich zamówiony u Marcina Marcińca przez kard. Fryderyka Jagiellończyka. Pracując dla króla Zygmunta I Starego, jako złotnik nadworny, w latach 1510-1511 poza innymi pracami wykonał Marciniec srebrne dzbany, półmiski, klamry do pasów, rękojeści do mieczów, zapinki itp., za co otrzymał wysoką sumę 100 grzywien. Zapewne większe zamówienie stanowiły srebrne, złocone „obrazy” wykonane przez mistrza Marcina w r. 1512 z przeznaczeniem do ołtarza św. Stanisława biskupa w katedrze na Wawelu, ufundowane przez króla Zygmunta I Starego, za które zapłacono wysoką sumę 410 florenów. Wreszcie z r. 1519 zachowała się archiwalna notatka o złotym kielichu wykonanym dla kapituły krakowskiej z legatu Jana Rabsztyńskiego, marszałka nadwornego.

$\mathrm{Na}$ podstawie faktu, iż Marcin Marciniec związany był z kard. Fryderykiem Jagiellończykiem, i podobieństw, głównie w zakresie dekoracji, z relikwiarzem św. Stanisława biskupa z r. 1505, Adam Bochnak i Julian Pagaczewski związali z osobą złotnika dalsze dzieła, mianowicie krzyż, tzw. większy, z lat 1493-1503, ofiarowany katedrze gnieźnieńskiej, oraz berło, wykonane w tymże czasie, darowane Akademii Krakowskiej, podobnie jak i krzyż przez kard. Fryderyka, wreszcie bogato dekorowany kielich, przechowywany $\mathrm{w}$ skarbcu kościoła parafialnego $\mathrm{w}$ Wieliczce ${ }^{11}$. Wszystkie te trzy atrybucje mają oczywiście charakter hipotetyczny. Natomiast bez przeprowadzania odpowiedniej analizy formalnej przypisano mistrzowi późnogotycki srebrny posążek św. Stanisława biskupa, przechowywany do ostatniej wojny w klasztorze paulinów na Skałce w Kra-

11 B ochnak, Pagaczewski, Polskie rzemiosto artystyczne..., s. 102-104 (ryc. 78). 
kowie, oraz monstrancję z r. 1499 w skarbcu kościoła parafialnego w Wieliczce ${ }^{12}$. Także przykrą pomyłką jest przypisanie Marcińcowi przez Bogusława Kopydłowskiego krzyża z r. 1510 w skarbcu klasztoru paulinów na Jasnej Górze w Częstochowie, na którym to krzyżu znajduje się cecha z literą N, wskazująca — jak słusznie sugerował to wcześniej Adam Bochnak - na wykonanie w Norymberdze ${ }^{13}$.

Chociaż wszystkie archiwalnie stwierdzone dzieła (oprócz relikwiarza św. Stanisława biskupa) nie zachowały się lub - co jest mało prawdopodobne - nie zostały zidentyfikowane, powyższe informacje pozwalają na podjęcie próby scharakteryzowania złotnika i określenia, jakie miejsce w jego dorobku zajmował relikwiarz św. Stanisława. Wykorzystana tu też będzie Pochwała wygłoszona po śmierci Marcińca. Wykszałcił się on w Krakowie, w warsztacie ojca, w okresie gdy lokalne złotnictwo przeżywało rozkwit — ,złoty wiek". Nie tylko zresztą pochodzenie ze znanej złotniczej rodziny uwarunkowało jego możliwości i zamożność. Poprzez związki (przez żonę i rodzeństwo) pozostawał on $\mathrm{w}$ kontaktach $\mathrm{z}$ innymi, bogatymi i cieszącymi się znaczeniem rodzinami mieszczańskimi. Pracował na rzecz możnowładców, króla i jego rodziny. Był złotnikiem, który wykonywał znaczną ilość prac, zarówno o kościelnym jak i świeckim przeznaczeniu. Powierzono mu do wykonania prace zarówno ze złota - co przecież nie było tak powszechne - jak i ze srebra. Zlecenie Marcińcowi wykonania "obrazów" do ołtarza św. Stanisława (podobne zamówienie otrzymał od króla Zygmunta I Starego norymberski złotnik Albert Glim) świadczy, że wykonywał on w Krakowie dzieła, dla których konkurencję stanowiły może tylko norymberskie wyroby. Nie wiadomo, w jakim stopniu posługiwał się wzorami graficznymi; posiadamy bowiem informację, że w warsztacie swoim miał wzory, które wraz z narzędziami przekazal swojemu wnukowi Mikołajowi, w nadziei, że i ten zostanie złotnikiem. Należy wreszcie dodać, że jako człowieka, jak świadczy opinia mu współczesnych, cechowała go uczciwość i życzliwy stosunek do otoczenia, zaś w wyglądzie zewnętrznym, dostojna postawa podkreślona przez bujne siwe włosy ${ }^{14}$.

Charakterystykę mistrza Marcina, jako złotnika, można wzbogacić uwagami nasuwającymi się $\mathrm{w}$ wyniku analizy złotego relikwiarza na głowę św. Stanisława w skarbcu katedry wawelskiej. Z dużą umiejętnością i zamiłowaniem stosował on plastyczną dekorację roślinną i architektoniczną. Radził sobie także nieźle ze scenami figuralnymi i postaciami ludzkimi, aczkolwiek w tym wypadku, aby uzyskać głębię wyrazu, w spe-

$12 \mathrm{~K}$ opy dłowski, jw., s. 242 (ryc. 6).

13 Tamże, s. 240 (ryc. 7), s. 241 (ryc. 8-9), s. 243; Sztuka w Krakowie w latach 1350-1550, Kraków 1964, s. $173-174$ (poz. 185, ryc. 82); B o chnak, Pagac zew ski, Polskie rzemiosto artystyczne..., s. 144.

14 D obrowolski, jw., s. 58. 
cyficzny sposób traktował postać ludzką przedstawioną w ruchu, nie bacząc na uchybienia w zakresie anatomii. Fakt ten nie dziwi, jeśli się zważy, że relikwiarz św. Stanisława jest dziełem na wskroś gotyckim; oznaki nowego stylu widzieć można tylko w formach tarcz herbowych trzymanych przez anioły oraz maiuskułowych napisach. Fakt, że umieścił na relikwiarzu, wprawdzie we wnętrzu, swoją sygnaturę, można uważać za dowód poczucia własnej, wysokiej wartości jako artysty, świadomego ważności samego dzieła, dojrzałego pod tchnieniem nowej sztuki.

Marcin Marciniec, jak wynika to $\mathrm{z}$ analizy jego testamentu, miał bardzo osobisty, pełen zamiłowania stosunek do uprawianego kunsztu. Jakąż więc pozycję jego $\mathrm{w}$ twórczości zajmuje stanowiący przedmiot naszej pracy relikwiarz?. Było to najpewniej jego najokazalsze dzieło, a samego wykonawcę uznać można za jednego $\mathrm{z}$ najwybitniejszych złotników polskich czasów późnego gotyku. Od swych kolegów, czynnych we Wrocławiu czy Gdańsku, odróżniał się Marciniec może mniejszymi umiejętnościami w przedstawianiu postaci ludzkiej (jeśli jej celowo nie deformował). W stosunku do złotników działających na terenie środkowej Europy, gdzie na uwagę zasługuje przede wszystkim Norymberga, był mistrzem należącym - jak się wydaje - jeszcze do czasów późnego gotyku, podczas gdy oni działali już w duchu renesansu i manieryzmu. Jako złotnika realizującego kanony ,,jesieni średniowiecza" można go uznać za jednego z najwybitniejszych mistrzów w Europie, a z bliżej znanych nam artystów dobrze unaocznia nam to stwierdzenie zestawienie walorów relikwiarza św. Stanisława z dziełami związanymi ze złotnikiem wrocławskim Andrzejem Heideckierem ${ }^{15}$.

\section{III}

TYP WIELOBOCZNYCH, KOPUEOWYCH RELIKWIARZY W POLSCE

$\mathrm{Na}$ typ wielobocznych relikwiarzy kopułowych na głowę świętych zwrócił już uwagę Adam Bochnak, a jego rozważania podjął autor niniejszej rozprawy ${ }^{16}$. Pierwszy $\mathrm{z}$ wymienionych wspomina o dwunastu relikwiarzach tego typu - autor niniejszej rozprawy ustalił $\mathrm{z}$ górą trzydzieści wielobocznych relikwiarzy kopułowych zachowanych lub znanych z archiwaliów. Zasadniczo podzielić je można na cztery grupy: małopolską w. XV-XVI, wielkopolską w. XV-XVI, wielkopolsko-pomorską w. XVII,

15 Por. J. S a mek, Polskie zlotnictwo (w druku).

16 Por. A. Bochnak, Barth Jakub, [w:] Polski slownik biograficzny, t. 1 s. 311-312; B ochnak, Pagaczewski, Polskie rzemiosło artystyczne..., s. 169171, 172; J. Samek, Nawrót do gotyku $w$ sztuce Krakowa w pierwszej polowie w. XVII, „Folia Historiae Artium” 5 (1968) s. 110-112; tenże, Polskie złotnictwo (w druku). 
małopolską w. XVI-XIX. Według takiej też kolejności zostaną przedstawione znane nam obiekty, aby można było ustalić najwcześniejszą puszkę tego rodzaju oraz określić, co wydaje się szczególnie ważne, miejsce relikwiarza św. Stanisława w ciągu rozwojowym tego typu obiektów.

\section{Małopolskie relikwiarze wieloboczne $\mathrm{z}$ wieku XV-XVI}

Najwcześniejszym z zachowanych do naszych czasów małopolskich, wielobocznych relikwiarzy kopułowych jest puszka przeznaczona na głowę św. Stanisława, obecnie mieszcząca relikwie św. Floriana (ryc. 4), ufundowana w latach 1422-1461 przez Zofię, żonę króla Władysława Jagiełły ${ }^{17}$. Relikwiarz królewskiej fundacji, wykonany ze srebra, pozłacany, ma kształt wspartej na kulach dwunastobocznej puszki, której ścianki mieszczą pod baldachimami posążki biskupów i aniołów. Ozdobiona rytem i minuskułowym napisem spłaszczona kopułka opatrzona została wziernikiem. W przekonywający sposób ustalił ks. Bolesław Przybyszewski, że na relikwiarzu z ikonograficznego punktu widzenia przedstawiona została Civitas Sancta ${ }^{18}$. W sferze hipotez pozostaje natomiast wysunięta przez tegoż autora sugestia, jakoby relikwiarz ten został wykonany przez złotnika Marcina Goldsmeda, pozostającego na usługach dworu królewskiego. Z artystycznego punktu widzenia relikwiarz cechuje zgrabna kompozycja przy dość surowej rzeźbie figuralnej i mało finezyjnej architektoniczno-roślinnej dekoracji.

Z kolei należałoby wymienić skromny relikwiarz św. Urszuli, pochodzący z około połowy w. XV lub może z drugiej połowy tegoż stulecia (ryc. 5), należący ongiś do kościoła św. Szczepana w Krakowie i przechowywany dzisiaj w nowej świątyni pod tym wezwaniem ${ }^{19}$. Wykonany ze srebra, pozłacany, posiada kształt sześciobocznej puszki przykrytej kopułką z wziernikiem. Narożniki ścianek, opatrzonych prostokątnymi otworami z szybkami, zaakcentowano za pomocą szkarp, przy czym jedyną właściwie ozdobę relikwiarza stanowi delikatna koronka umieszczona $u$ podstawy kopułki. Całość zgrabna w formie należy do typu skromnych rozwiązań, których zaletą są wyważone proporcje i logicznie rozmieszczona dekoracja.

17 Przeździecki, Rastawiecki, jw., tabl.; Z. Essenwein, Die mittelterlichen Kunstdenkmale der Stadt Krakau, Leipzig 1869, s. 173 (ryc. 94): Polkowski, jw.; B. Przybyszewski, Złoty Dom Królestwa. Studium $z$ dziejów krakowskiego cechu zlotniczego od czasu jego powstania (ok. 1370) do połowy wieku XV, Warszawa 1968, s. 51-53.

$18 \mathrm{Przy}$ byszewski, jw., s. 53-54.

$19 \mathrm{~J}$. Pagacze w ski, Dwa relikwiarze $w$ skarbcu parafialnym kościoła $N$. P. Marii na Piasku w Krakowie, "Sprawozdania Komisji Historii Sztuki” 9 (1915) s. CXLIX (ryc. 22); Przybyszewski, jw., s. 143-146. 
Z kolei wymienić by należało opisaną już dokładnie puszkę na głowę św. Stanisława z r. 1505 oraz wykonany zapewne w tym samym czasie relikwiarz (zaginiony $\mathrm{w}$ czasie ostatniej wojny) $\mathrm{z}$ daru Boruty, datowany na początek, może na drugą dekadę w. XVI (ryc. 6). Relikwiarz ten, pochodzący ze Stopnicy, znany dzięki zachowanym zdjęciom i opisowi, był, podobnie jak i puszka św. Urszuli, sześcioboczny, przykryty opatrzoną listwami kopułką z wziernikiem ${ }^{20}$. I tu narożniki zaakcentowano bardziej rozbudowanymi w duchu późnego gotyku szkarpami, połączonymi w oryginalny sposób rodzajem daszków z krenelażem u podstawy kopułki. O ile ścianki ożywiają tylko prostokątne otwory z powtarzającymi się motywami roślinnymi, poszczególne pola pokrywy wypełniono grawerunkami. Są to śmiało ryte przedstawienia: Matki Boskiej z Dzieciątkiem, Sw. Urszuli, Sw. Piotra, Sw. Pawła, Chrystusa wstającego z grobu w otoczeniu Narzędzi Męki Pańskiej oraz kartusz z herbem Pobóg i minuskułowym napisem „borutha”. Wspomniane ryty stanowią największą wartość stopnickiego relikwiarza, który $\mathrm{w}$ proporcjach jest - rzecz szczególna bardzo bliski relikwiarzowi św. Urszuli.

Niestety nieznany jest dokładny czas powstania niezachowanych do naszych czasów relikwiarzy puszkowych, m.in. relikwiarza na głowę św. Floriana z herbami Pogoń, Dębno i Kapituły oraz na głowę św. Urszuli, gdzie widniał herb kard. Fryderyka Jagiellończyka i kapituły - Jastrzębiec i Jednorożec. Relikwiarze te wymienia inwentarz skarbca katedry wawelskiej z r. 1563.

Natomiast tylko połowicznie należy do naszej grupy okrągły, przykryty kopułką, bogato dekorowany masą perłową relikwiarz na głowę św. Szczepana, przechowywany w nowym kościele pod tym wezwaniem, datowany na drugą ćwierć w. XVI ${ }^{21}$. Srebrny, pokryty masą perłową, złoconymi okuciami z dekoracją roślinną, relikwiarz ten uważany jest, co wymaga weryfikacji, za import norymberski. Dostrzeżono w nim także związki z wzorami Piotra Flötnera.

Sumując, do chwili obecnej zachowały się w Małopolsce trzy wieloboczne relikwiarze kopułowe $\mathrm{z}$ w. XV-XVI, przy czym zaznaczyć należy, że było prawdopodobnie - jak wskazują archiwalia - więcej.

\section{Wielkopolskie relikwiarze wieloboczne $\mathrm{z}$ wieku XV-XVI}

Z terenu Wielkopolski znamy znacznie więcej wielobocznych relikwiarzy kopułowych aniżeli z obszaru Polski południowej. Za najwcześniejszy uchodzi relikwiarz św. Urszuli w katedrze gnieźnieńskiej z r.

20 Sichergestelte Kunstwerk in Generalgouvernement, s. 84 ( $\mathrm{nr} 274)$; B o c h nak $P$ agaczewski, Polskie rzemiosto artystyczne..., s. 136, 137-139.

${ }_{21} \mathrm{P}$ a g a c zewski, jw., s. CXLIX (ryc. 23, 24). 


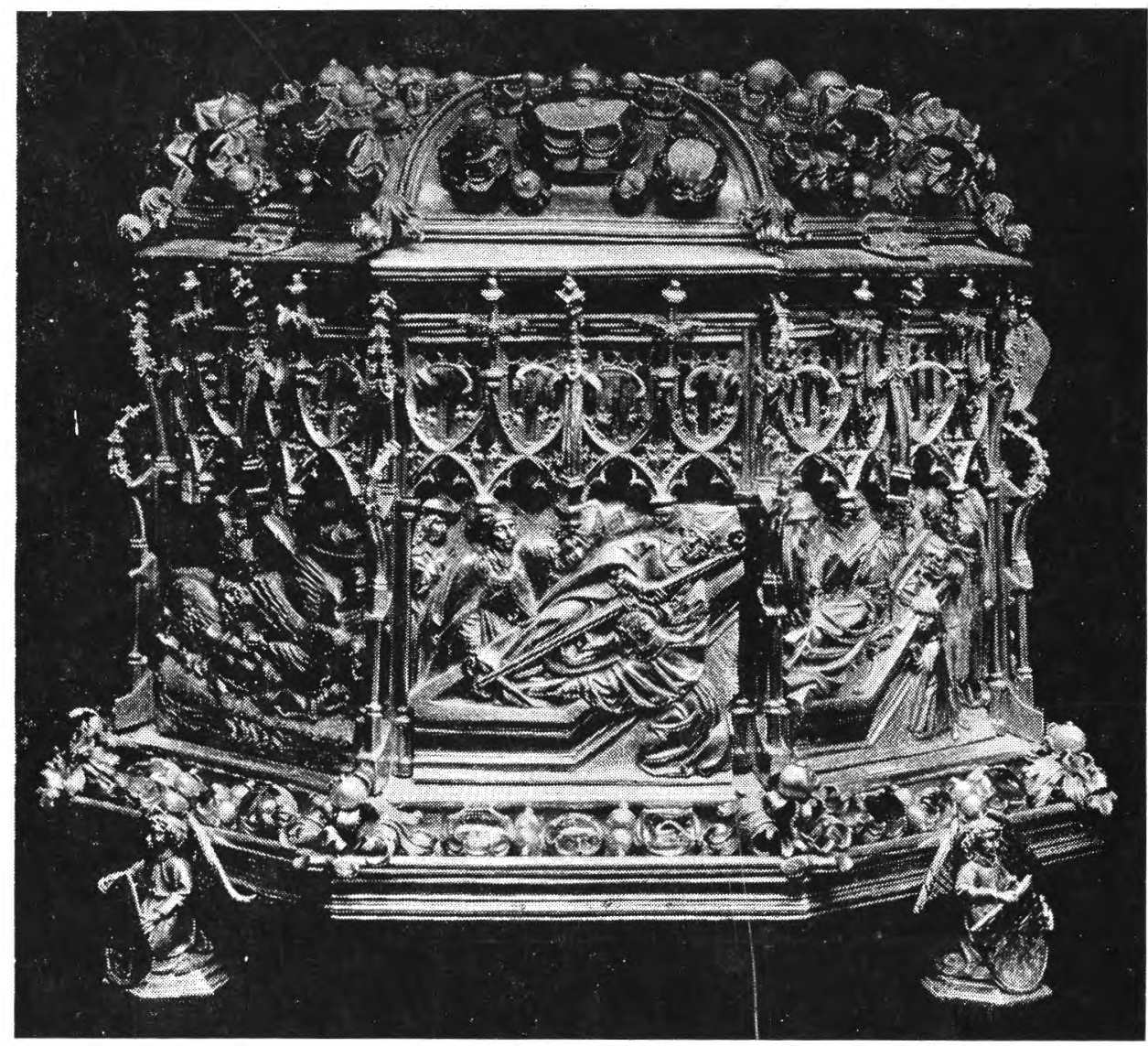

1a. Relikwiarz św. Stanisława biskupa z 1505 r. w skarbcu katedry na Wawelu. Marcin Marciniec. Fot. S. Kolowca. 


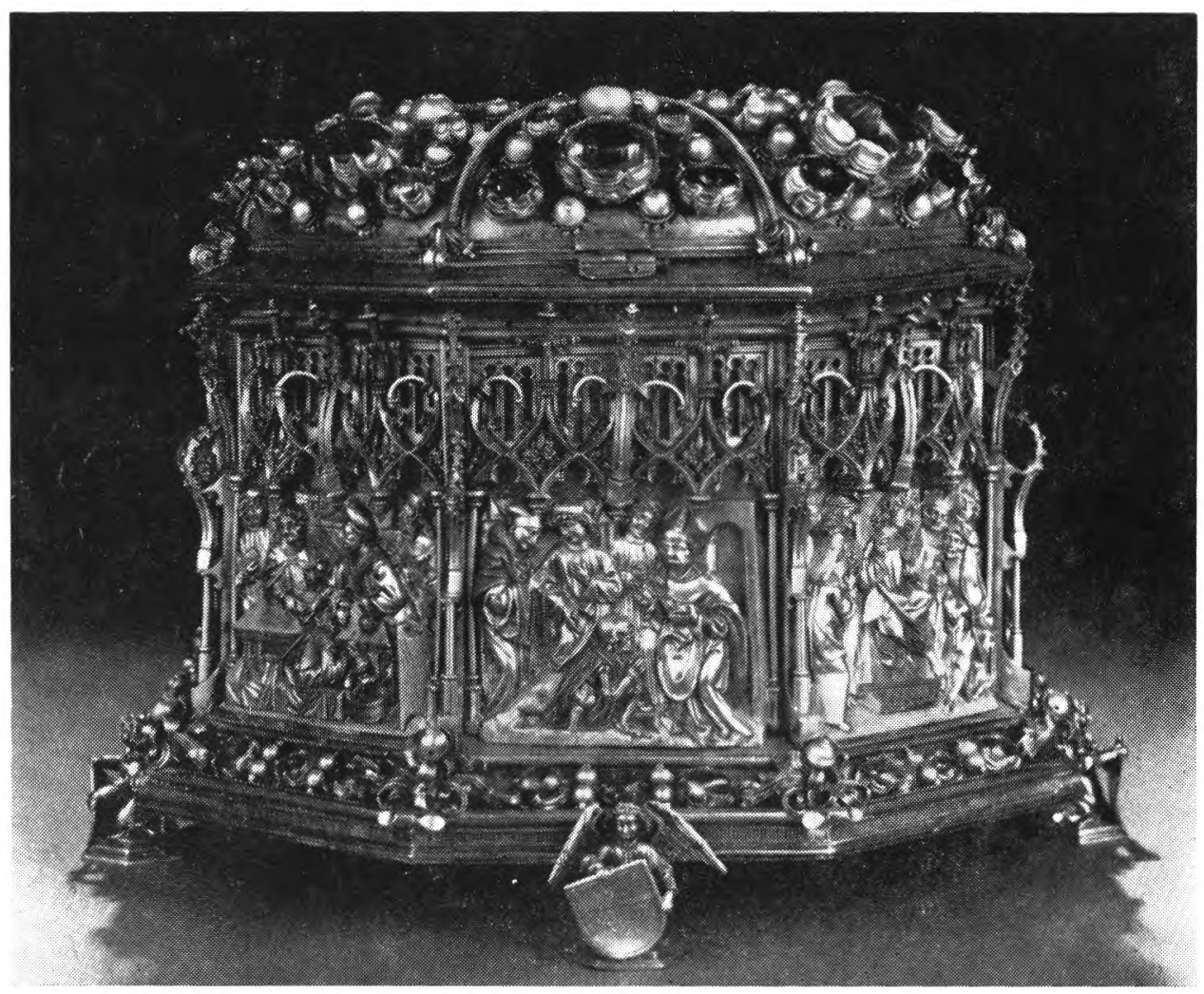

1b. Relikwiarz św. Stanisława biskupa z 1505 r. w skarbcu katedry na Wawelu Marcin Marciniec. Fot. S. Kolowca. 


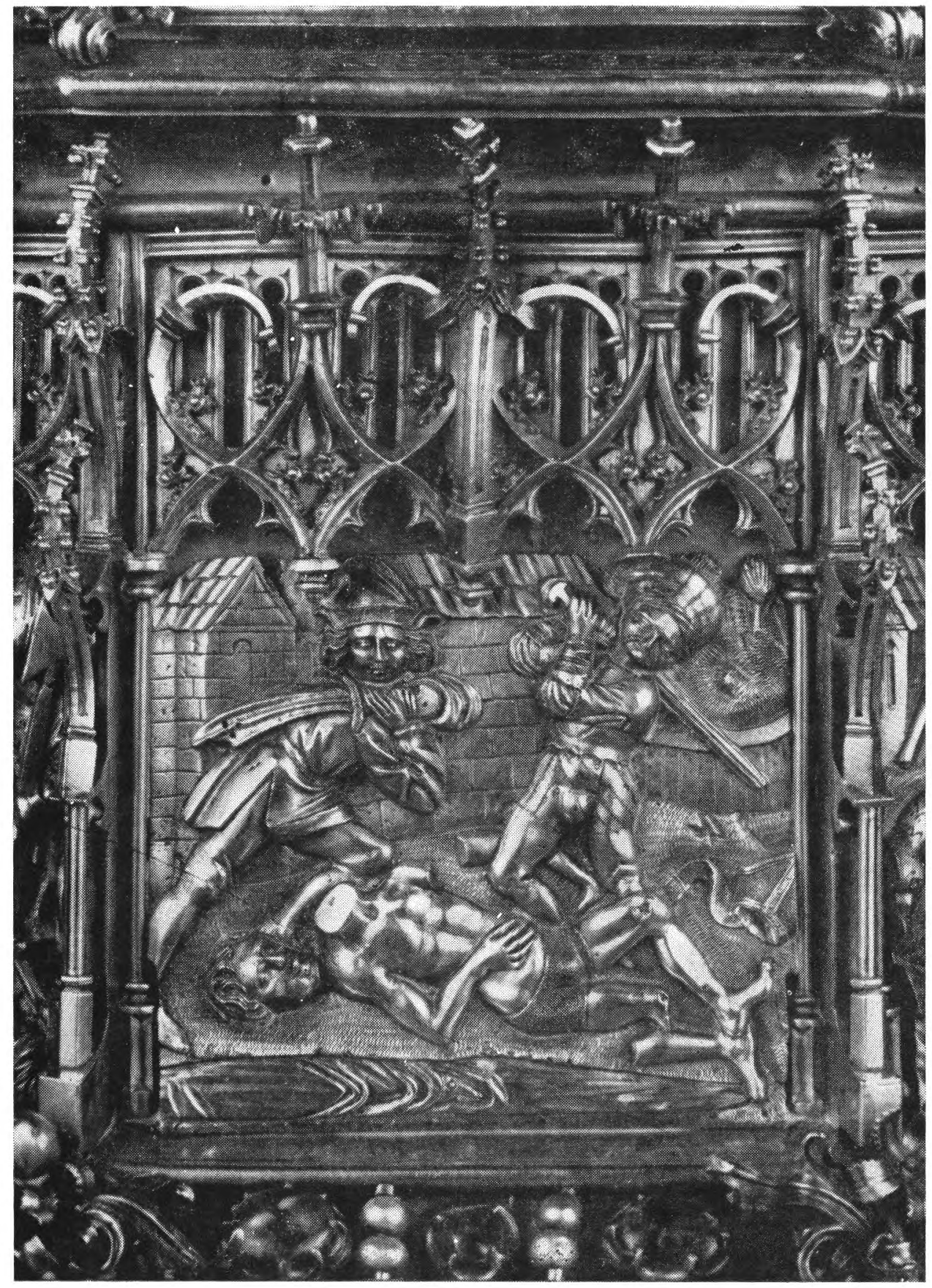

2a. Szczegół relikwiarza św. Stanisława biskupa z 1505 r. w skarbcu katedry na Wawelu. Marcin Marciniec. 


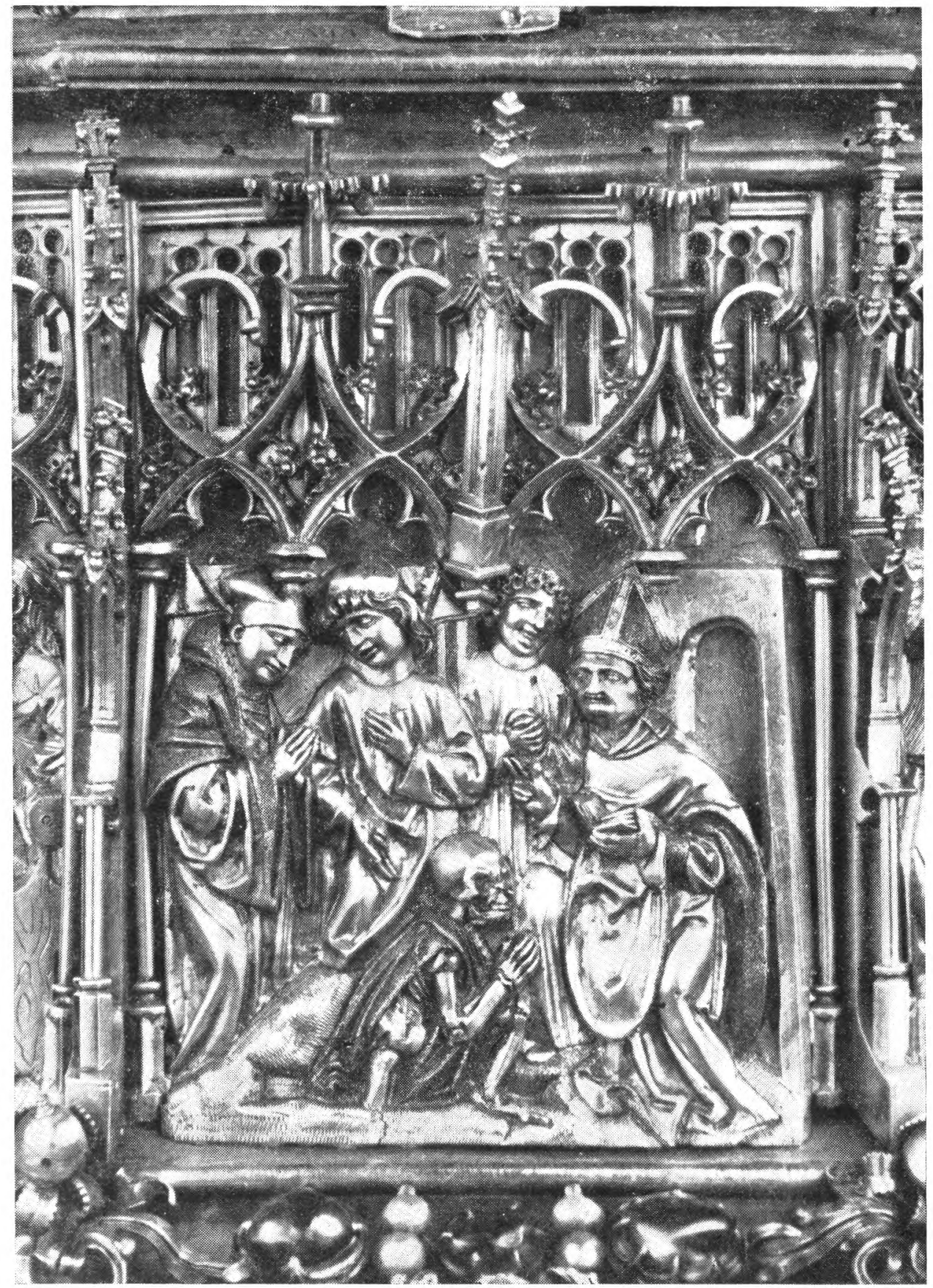

2b. Szczegół relikwiarza św. Stanisława biskupa z 1505 r. w skarbcu katedry na Wawelu. Marcin Marciniec. 


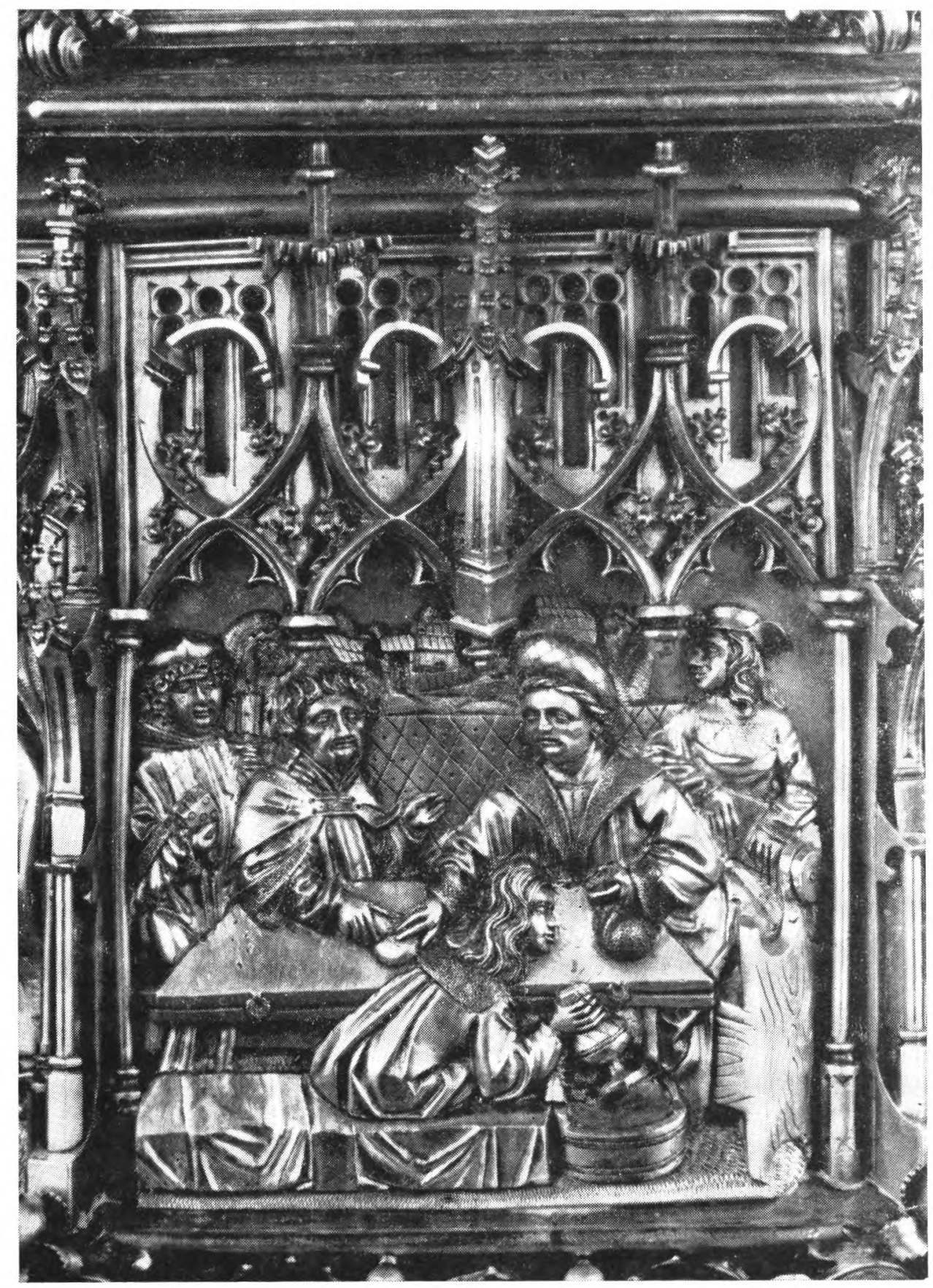

2c. Szczegół relikwiarza św. Stanisława biskupa z 1505 r. w skarbcu katedry na Wawelu. Marcin Marciniec. 


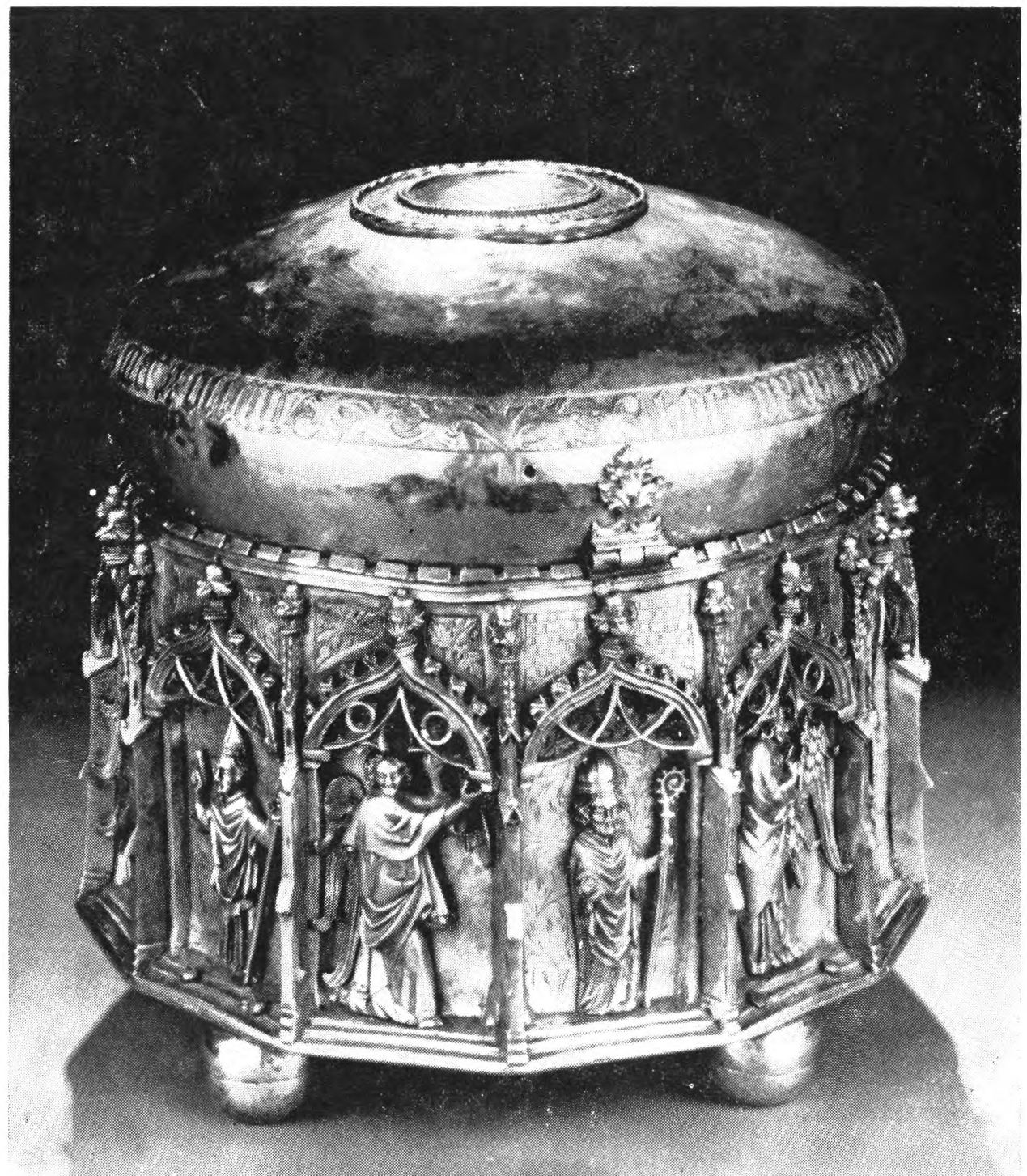

3. Relikwiarz św. Floriana (pierwotnie św. Stanisława biskupa) fundacji królowej Zofii, żony Władysława Jagiełły $\mathrm{z}$ lat $1422-1461 \mathrm{w}$ skarbcu katedry na Wawelu. Fot. W. Kryński. 


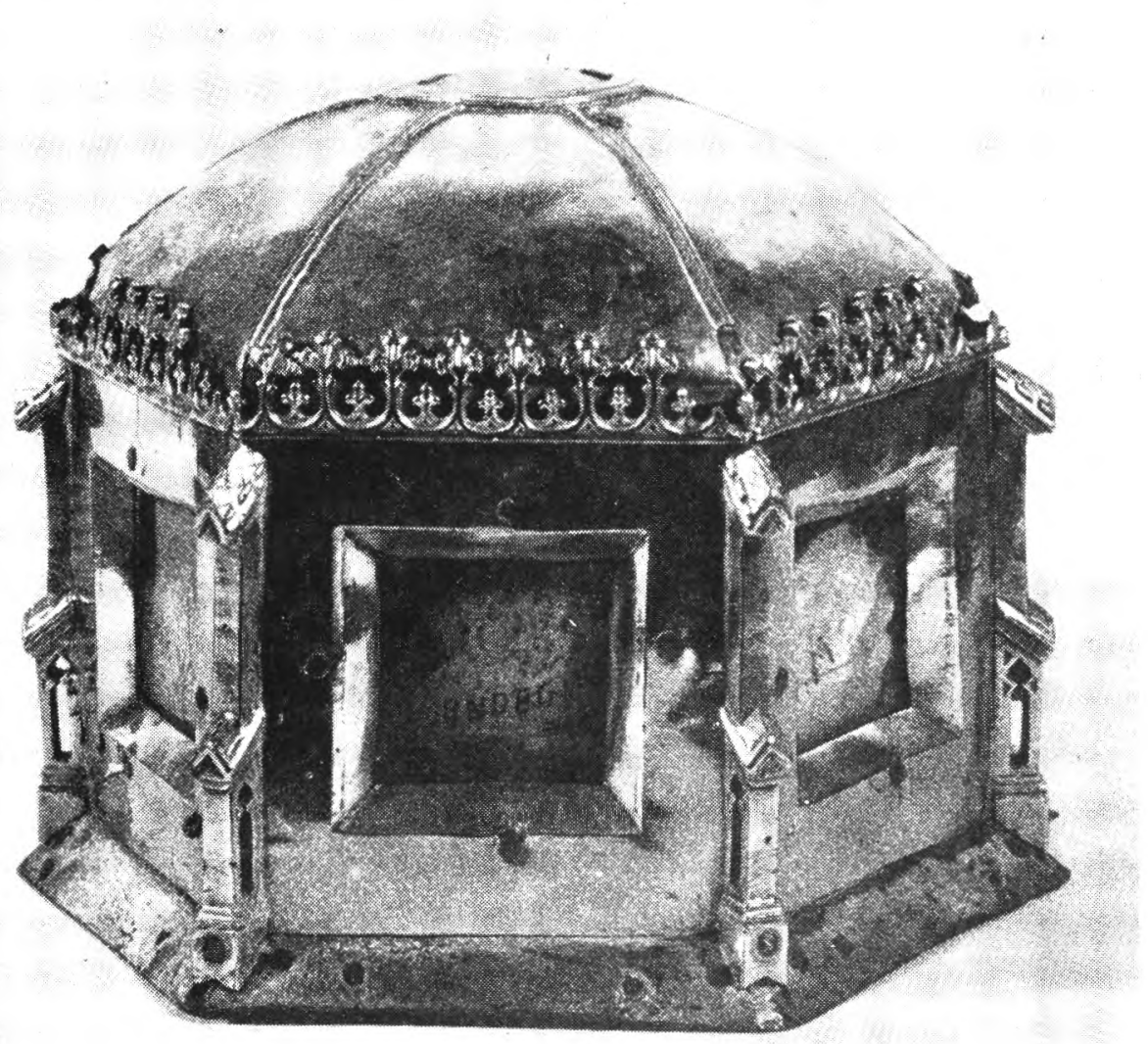

4. Relikwiarz św. Urszuli z około połowy XV w. w kościele Sw. Szczepana w Krakowie. Fot. J. Langda. 


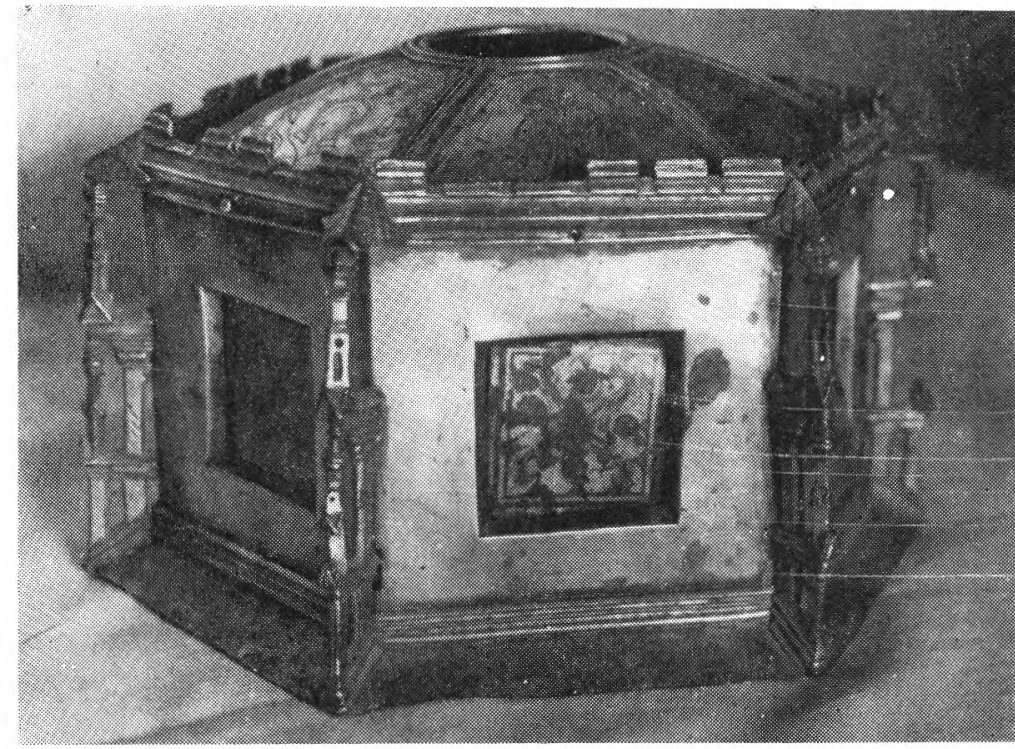

5. Relikwiarz fundacji Boruty z początku XVI w., dawniej w kościele parafialnym w Stopnicy (zaginiony).

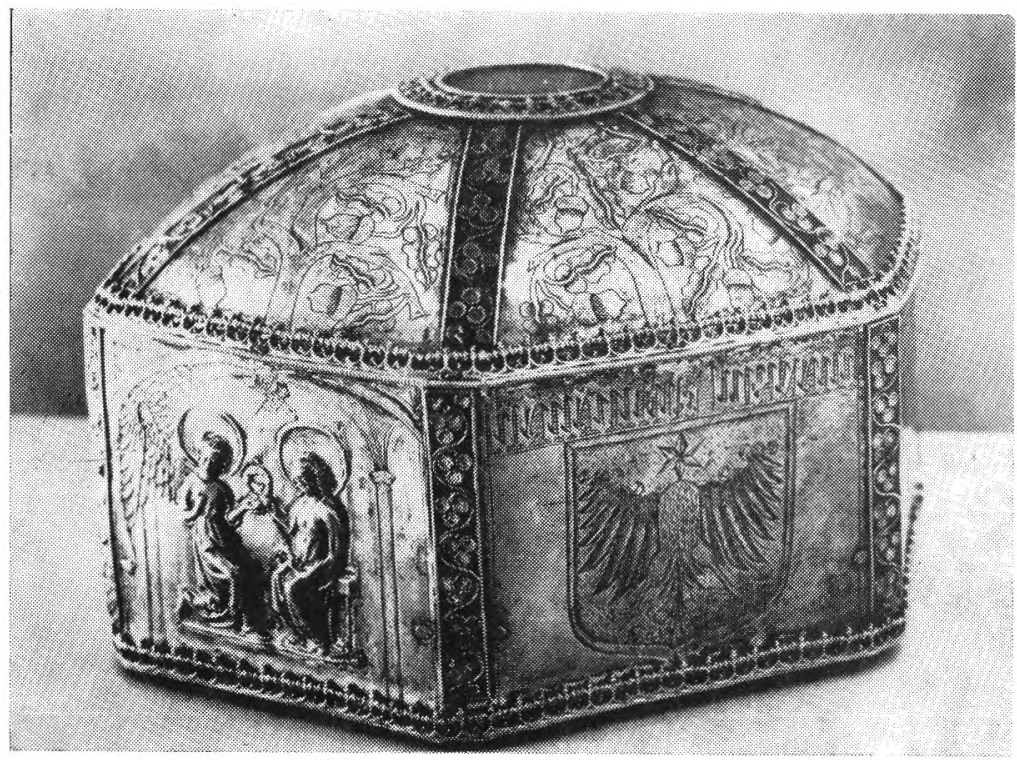

6. Relikwiarz św. Urszuli z fundacji Benedykta z Eopienna z 1481 r. w skarbcu katedry w Gnieźnie. 


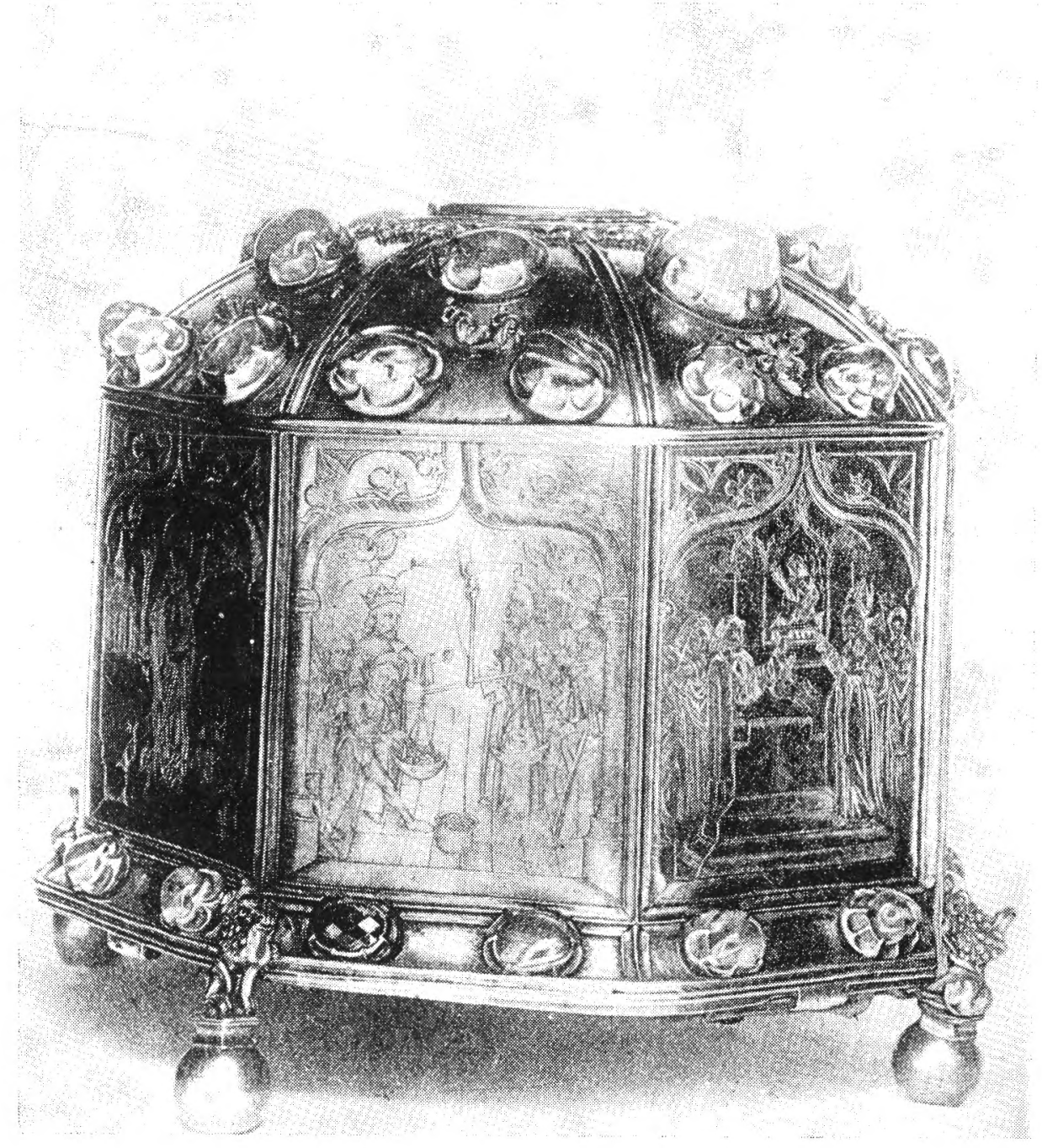

7. Relikwiarz św. Wojciecha z 1494 r., dawniej w skarbcu katedry gnieźnieńskiej (zaginiony). Jakub Barth. Fot. wedkug Kothego. 


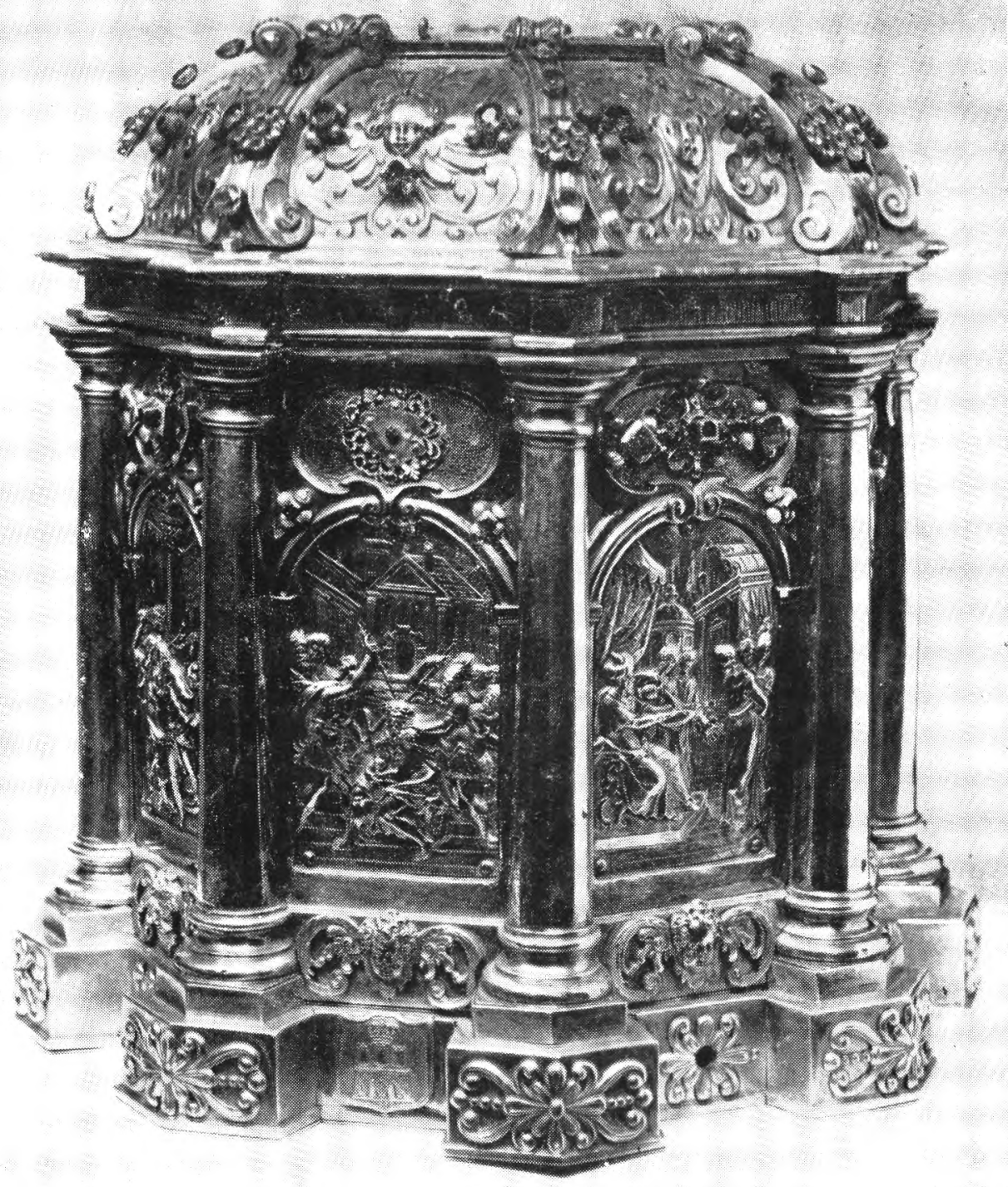

8. Relikwiarz św. Jacka z około 1611 r. w kościele dominikanów w Krakowie Fot. W. Gumuza. 
9. Anioł, obraz $\mathrm{z}$ lat $1619-1625 \mathrm{w}$ kaplicy św. Jacka w kościele Dominikanów w Krakowie. Tomasz Dolabella. Fot. J. Langda.

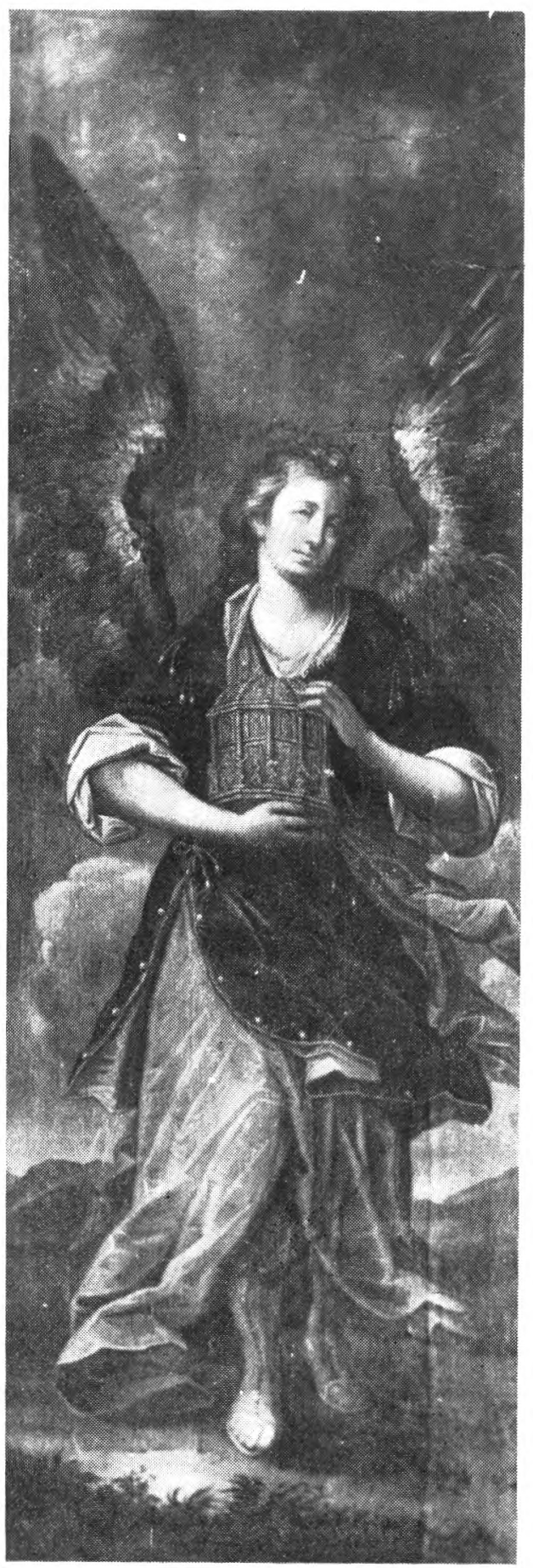




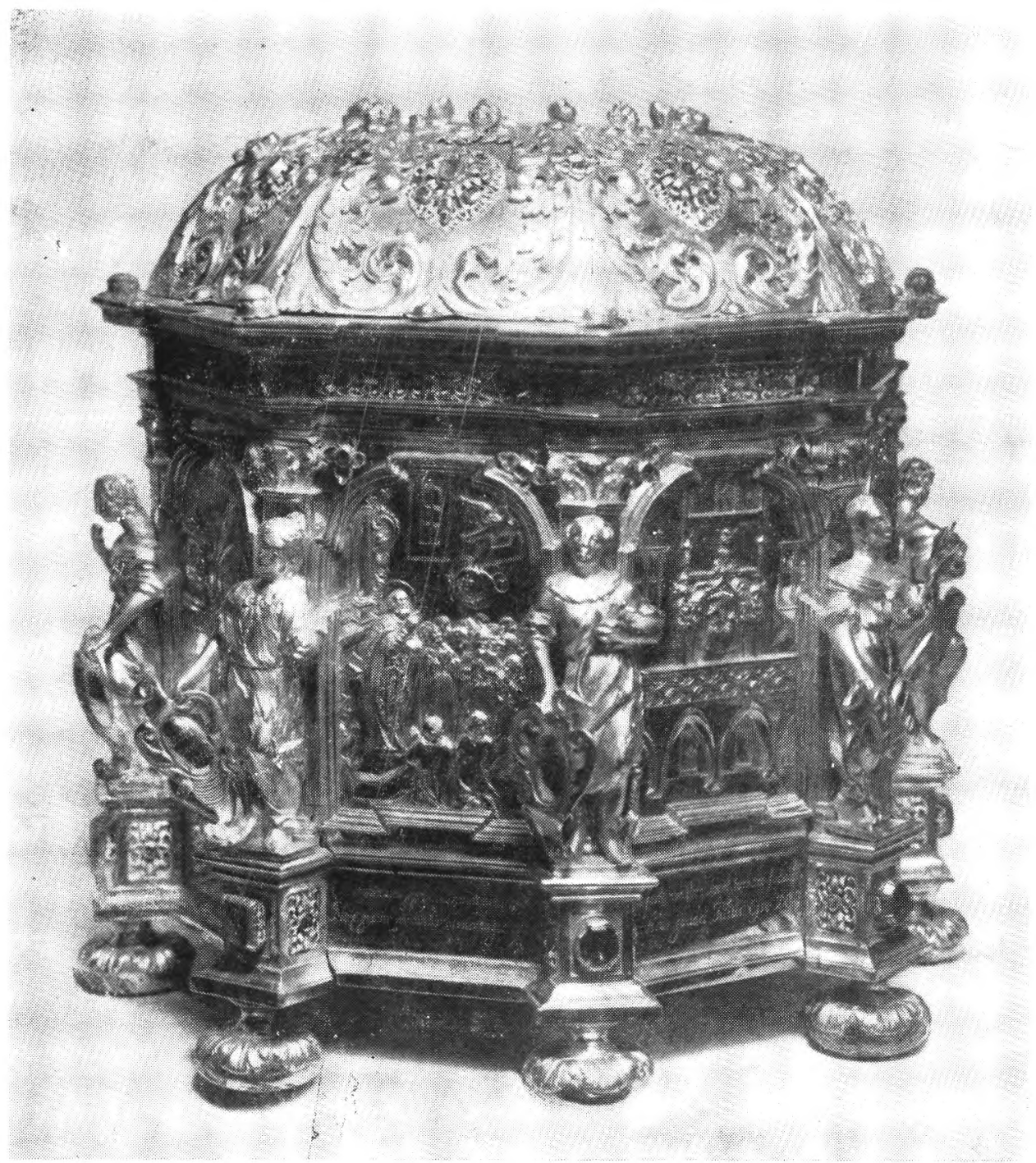

10. Relikwiarz św. Jana Kantego z 1695 r. w dawnej kolegiacie Sw. Anny w Krakowie. Jan Ceypler. Fot. W. Gumuła. 


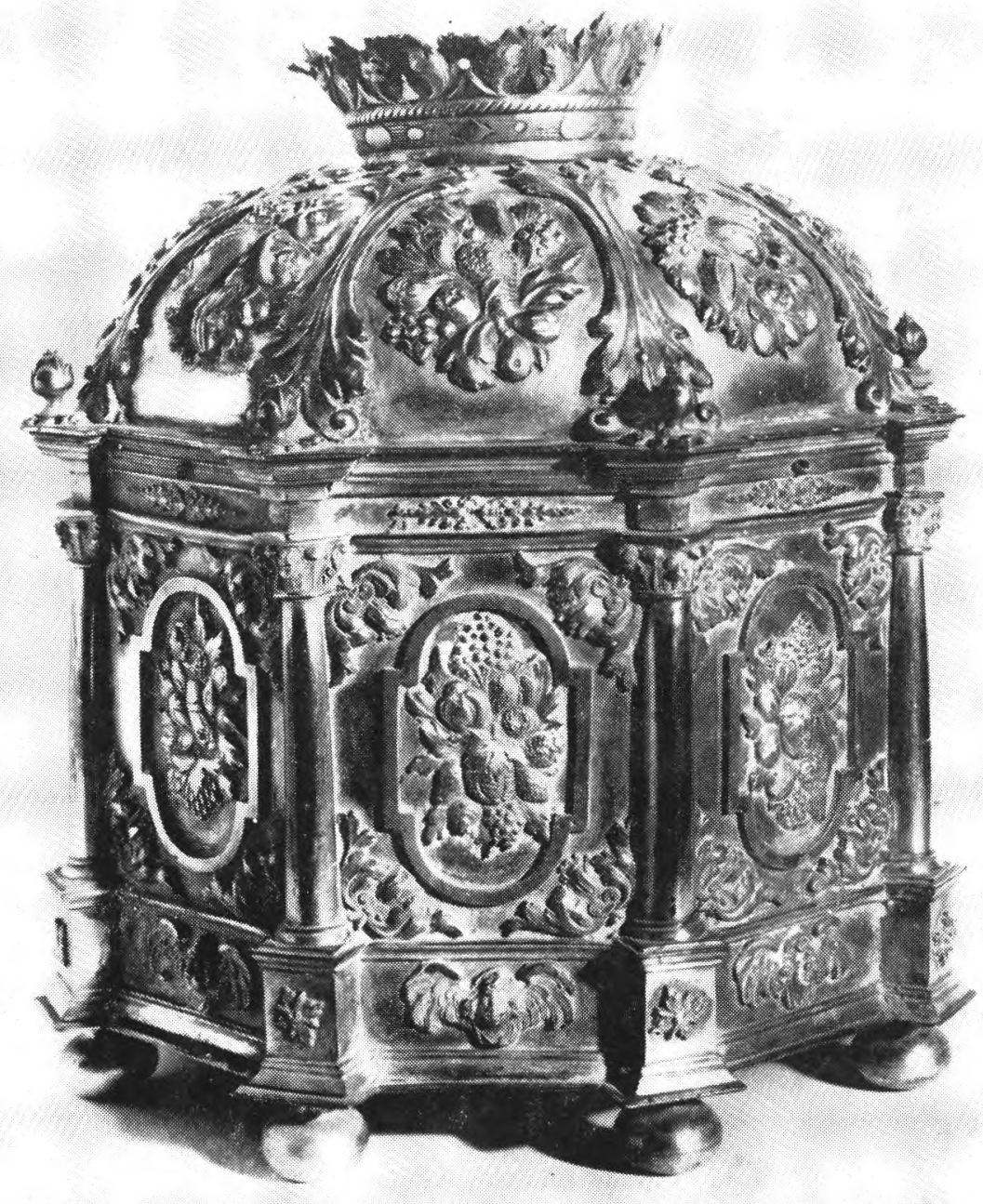

11. Relikwiarz św. Pauli fundacji księdza Władysława Opackiego z 1701 r. w kościele parafialnym w Kościelcu pod Proszowicami. Fot. W. Wolny. 


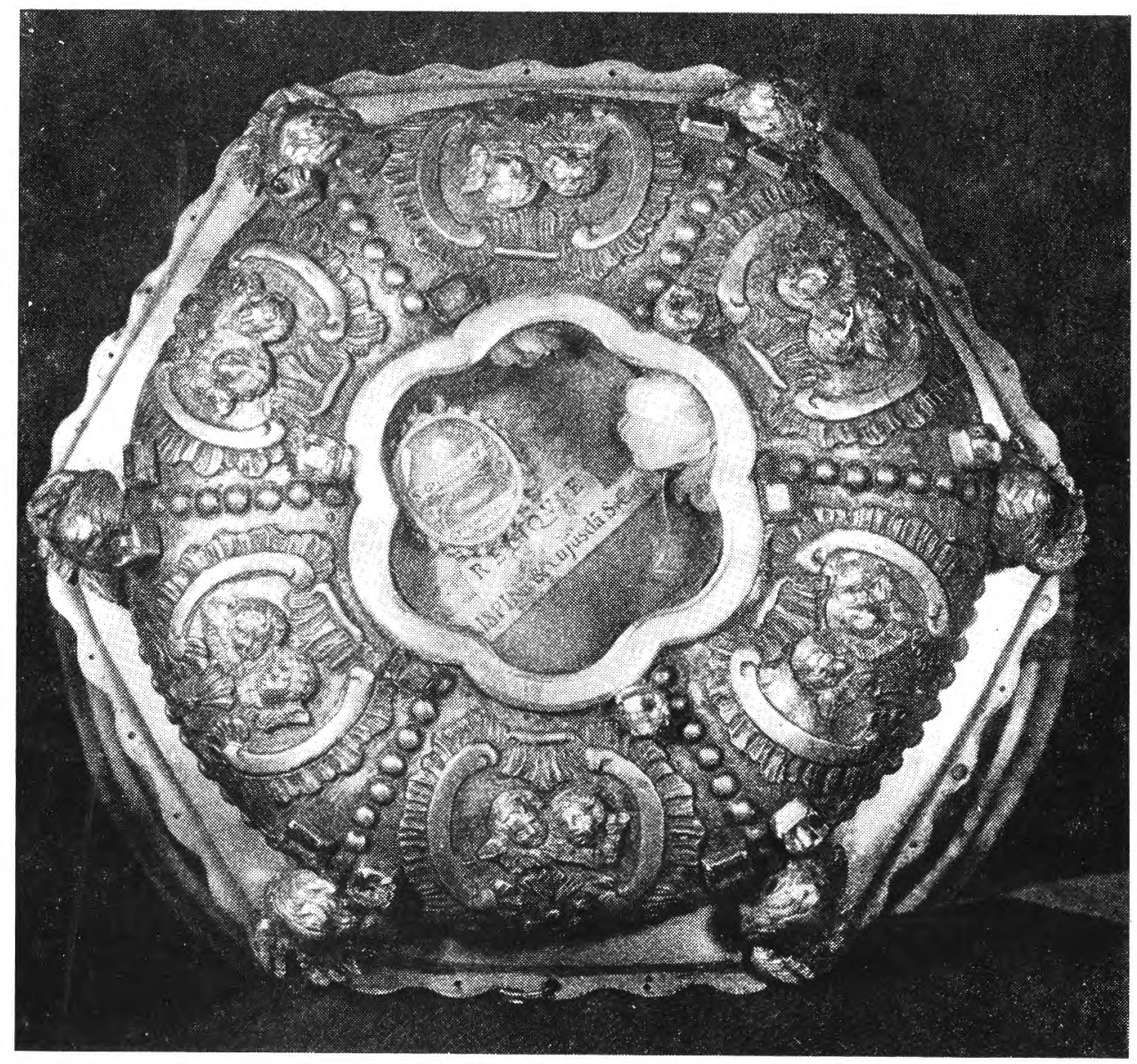

12. Wieko relikwiarza śś. Kryspina i Kryspiniana z 1779 r. w Kościele SS. Piotra i Pawła w Krakowie. Fot. J. Langda. 


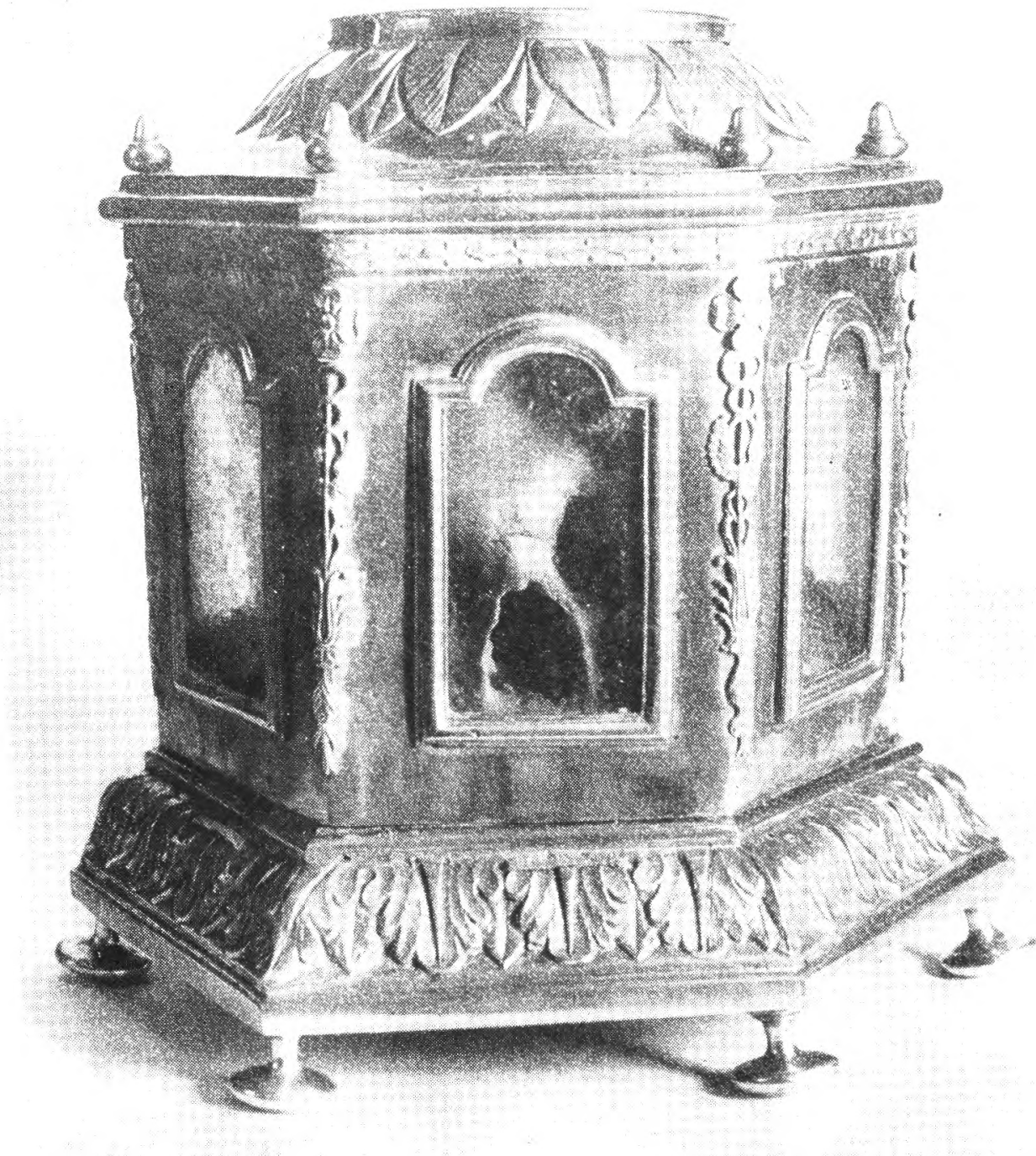

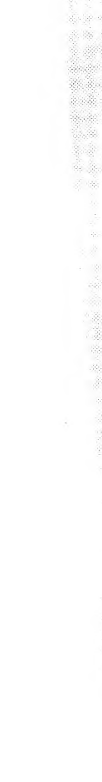




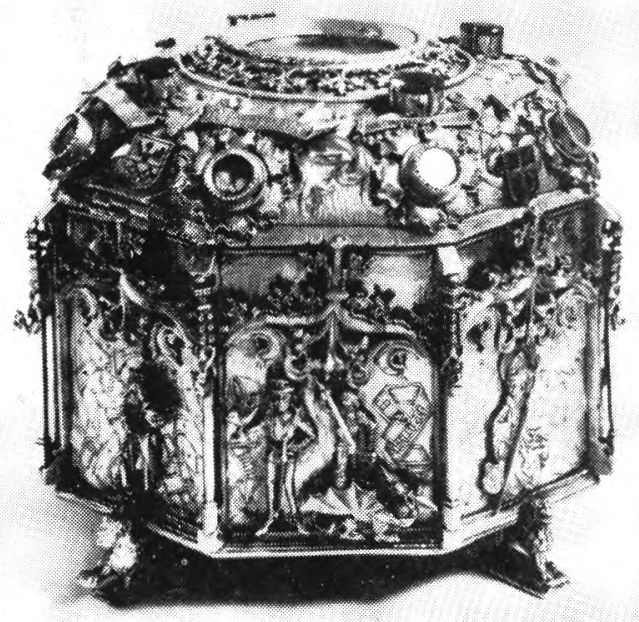

14. Relikwiarz św. Barbary z fundacji Jakuba z Boksicy z lat 1484-1493 w skarbcu katedry w Gnieźnie.

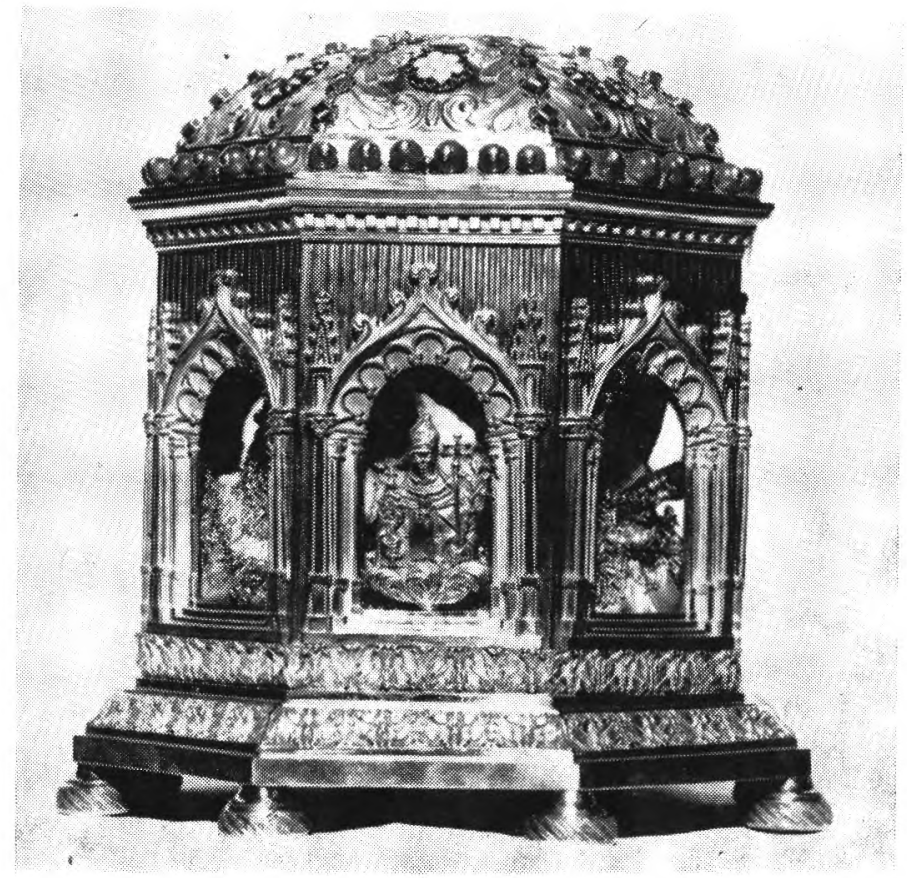

15. Relikwiarz bł. Bronisławy z 1840 r. w klasttorze Norbertanek w Krakowie. Franciszek Kausal. Fot. F. Stolot. 
1481 (ryc. 7), ufundowany przez Benedykta z Eopienna ${ }^{22}$. Puszka fundacji kanonika Benedykta ma kształt lekko wydłużonego sześcioboku, przykrytego kopułką z wziernikiem ${ }^{23}$. Ścianki ozdobiono plastycznymi scenami Zwiastowania i Ukrzyżowania oraz grawerunkami przedstawiającymi cztery herby, wśród nich Dębno kard. Zbigniewa Oleśnickiego i herb kapituły. Pola wieka zdobi powtarzający się motyw gałązki dębowej z liśćmi i żołędziami. Narożniki, wziernik oraz dolna i górne krawędzie ścianek zaakcentowano za pomocą fryzów roślinnych i poziomej koronki. Do dekoracji srebrnej puszki częściowo pozłacanej, zdobionej reliefem i grawerunkami, użyto emalii węgierskiej. Relikwiarz gnieźnieński, jak w ostatnich latach starano się udowodnić, nie jest dziełem jednolitym, plastyczne plakietki mają bowiem pochodzić z pierwszej połowy w. XV. Jako miejsce wykonania relikwiarza, którego dekoracja, szczególnie ryty, wykazują bardzo wysoki poziom artystyczny, wskazywany jest Poznań, co nie zostało jednak poparte żadnym dowodem. Można też wysunąć hipotezę (biorąc za punkt wyjścia użytą w dekoracji puszki emalię), że powstał on w warsztacie złotnika wykształconego w obcym ośrodku (Węgry ?).

Niewiele później wykonano inny wieloboczny relikwiarz gnieźnieński św. Barbary. Czas jego powstania określa się na lata około 1484-1493. Jest to dar Jakuba z Boksicy, profesora Akademii Krakowskiej, wikariusza generalnego w Gnieźnie ${ }^{24}$. Tutaj zastosowano już formę ośmiobocznej puszki wspartej na posążkach lwów, przykrytej kopułką z wziernikiem. Ścianki jej są ozdobione umieszczonymi pod baldachimami plastycznymi scenkami z wygrawerowanymi napisami na banderolach. Wyobrażono tu Matkę Boską z Dzieciątkiem, królów i świętych: Jerzego, Wojciecha, Jakuba Pielgrzyma, Gereona, Eufemię. Dekorację wieka stanowią przywiezione przez Boksicę z Ziemi Świętej kamienie w ozdobnych oprawach z napisami; tutaj też umieszczono cztery tarcze z herbami: Tarnawa (fundatora), Dębno, Nieczuja i Sulima. Główne wrażenie, jakie odnosimy oglądając relikwiarz św. Barbary, to efekt bogactwa, przy czym wybija się tu przede wszystkim plastyczna dekoracja, obok stojącej na dość przeciętnym poziomie rzeźby figuralnej. Przesądza to o wykonaniu dzieła w lokalnym, zapewne poznańskim warsztacie złotniczym.

Na szczególną uwagę zasługuje relikwiarz św. Wojciecha (ryc. 9) ufun-

\footnotetext{
22 Swiadczy o tym napis: BENEDICTVS LOPYENO ME FECIT PRO ECCLESIA GNESZNENSI ANNO DOMINI 1481.

${ }^{23}$ I. P olkow ski, Katedra gnieznieńska, Gniezno 1874, s. 243 (tabl. XVIII); Bochnak, Pagaczewski, Polskie rzemiosto artystyczne..., s. 109, 163-166, $166-167$.

24 A. Birkenmajer, L. Wachholz, Boksica Jakub, [w:] Polski stownik biograficzny, t. 1 s. 244-245; Powiat gnieźnieński, [w:] Katalog zabytków sztuki $w$ Polsce 5: Województwo poznańskie z. 3, opr. T. R u s z z ýska, A. Sławska i inni, Warszawa 1963, s. 37 (ryc. 435); Katedra gnieźnieńska, Poznań-Warszawa-Lublin 1970 , s. $365,376-380$.
} 
dowany dla katedry gnieźnieńskiej w r. 1494, jako dzieło autoryzowane ${ }^{25}$. Puszka ta wykonana została przez poznańskiego złotnika Jakuba Bartha. Zabytek ten niestety nie doirwał do naszych czasów, został bowiem skradziony w r. 1926. O wyglądzie obiektu dobrze informuje galwanoplastyczna kopia przechowywana w Muzeum Narodowym w Poznaniu oraz szczegółowe fotografie. Podobnie jak relikwiarz św. Stanisława w katedrze krakowskiej, wcześniejszy odeń relikwiarz na głowę św. Wojciecha wykonany był ze złota i posiadał kształt ośmiobocznej puszki wspartej na kulach, na których umieszczono postacie lwów. W dolnej części puszki znajdował się wydatny gzyms, ścianki wieńczyła spłaszczona kopułka z okrągłym kryształowym wziernikiem. Poszczególne pola relikwiarza wypełniono ośmioma scenami z życia św. Wojciecha pod ozdobnymi baldachimami, a wydobytymi za pomocą rytów. Przedstawiono tutaj: Ofiarowanie św. Wojciecha w kościele przez jego rodziców, Oddanie św. Wojciecha na nauki biskupowi magdeburskiemu, Wypędzenie przez św. Wojciecha czarta $z$ opętanego, Nauczanie Prusaków przez św. Wojciecha, Męczeństwo św. Wojciecha, Sw w. Wojciech przy kościele, Wykupienie ciała św. Wojciecha od Prusaków przez Bolesława Chrobrego. W scenach tych uczestniczy duża ilość symetrycznie rozmieszczonych postaci - stanowić by one mogły zresztą przedmiot osobnego studium. Na niezmiernie bogata kameryzację relikwiarza składały się dwadzieścia cztery duże szafiry oraz osiem pereł (na wieku), nadto osiem dalszych szafirów na cokole.

Za przykładem relikwiarza św. Wojciecha w katedrze gnieźnieńskiej, także innym relikwiarzem wielkopolskim nadawano kształt sześciobocznej lub cśmiobocznej puszki przykrytej kopułką, ozdobionej grawerunkami. Swiadczy o tym relikwiarz św. Otylii z r. 1496 przechowywany w dawnej kolegiacie w Szamotułach ${ }^{26}$. Sześcioboczna puszka z Szamotuł posiada nawet zbliżone do gnieźnieńskiej proporcje, nie opatrzono jej jednak cokołem, brak również kameryzacji. Na poszczególnych ściankach wyơrawerowano wnęki zamknięte łukiem trójlistnym, ściętym, mieszczące postacie: św. Otylii, jej ojca, śś. Marcina z żebrakami, Stanisława, Katarzyny i Barbary. Na polach wieka rozwija się banderola z napisem, wziernik, jak i w Gnieźnie, zaakcentowano koronką. I ten relikwiarz, którego główną wartość stanowią ryty, łączy się z poznańskim środowiskiem złotniczym.

Do wielkopolskich późnogotyckich, wielobocznych puszek relikwiarzowych należy także ośmioboczny kopułowy relikwiarz, obecnie pozbawio-

25 B ochnak, Barth Jakub..., s. 311-312; Katedra gnieźnieńska..., s. 380-381; Bochnak, Pagaczewski, Polskie rzemiosło artystyczne..., s. 169-172. Wysokość $22,1 \mathrm{~cm}$, obwód $71,2 \mathrm{~cm}$.

${ }_{29}$ Powiat szamotulski, [w.] Katalog zabytków sztuki w Polsce 5: Województwo poznańskie z. 23 , opr. R. i T. Juraszowie, T. Ruszczyńska, A. Sławska, Warszawa 1966, s. 28 (ryc. 152). 
ny ckna, datowany na pierwszą połowę w. XVI (powstały zapewne jeszcze w pierwszej ćwierci tegoż stulecia), przechowywany w kościele parafialnym pw. św. Wita w Rogoźnie, pochodzacy z Objezierza ${ }^{27}$. Ścianki i pola wieka tej puszki zdobi ryta dekoracja maswerkowa, nadto na dwóch polach pokrywy umieszczono herb Łodzia oraz gmerk z literami CS.

Bogaciej potraktowane zostały trzy inne puszkowe relikwiarze przechowywane w katedrach w Gniénnie i Poznaniu. Najwcześniejszym z nich jest relikwiarz św. Sabiny z r. 1510 wiązany z warsztatem złotnika poznańskieso Piotra Gelhora, przechowywany w katedrze w Pcznaniu ${ }^{23}$. Posiada cn kształt cśmiobocznej puszki przykrytej spłaszczoną kopułka z wziernikiem - podstawę stanowi motyw uschniętej gałęzi z jabłkami, co uznawane jest za oznakę nowego stylu. I tutaj ścianki oraz wieko ozdobiono srawerunkami. Na ściankach wyryto w trójlistnych arkadach sceny z nęczeństwa św. Katarzyny, przedstawienia śś. Piotra, Pawła i Wawrzyrica, wreszcie napis dotyczący fundacji puszki przez kanonika Wawrzynca Grodzickię̧. Narożniki zaakcentowano przy pomocy plastycznych, wątłych, kreconych kolumienek; wieko ożywiają rozchodzące się od wziernika promienie.

Znacznie niższy poziom artystyezny cechuje relikwiarz św. Jckundyna (pierwotnie św. Urszuli i jej towarzyszek), ufundowany w r. 1522 do katedry w Poznaniu przez nieznanego bliżej kanonika herbu Sulima ${ }^{29}$. Pelikwiarz ten, o formie ośmiobocznej puszki, o wieku z okracłym wziernikiem podzielonym na pola, posiada wyraźnie zaznaczony cokół, zaś w zwieńczeniu ścian koronkę złożoną z motywów winnej latorośli. Ścianłi ozciobiono rytami o na poły ludowym charakterze. Są to umieszczone na przemian duże symetryczne motywy roślinne i scenki figuralne, m.in. Matka Boska z Dzieciątkiem i klęczącym fundatorem; pole wieka zdobią ry乞e motywy maswerkowe. Relikwiarz św. Jokudyna świadczy o trwaniu typu, ale i o podupadaniu techniki grawerunku w środowisku poznańskim.

$\mathrm{Na}$ pograniczu gotyku i renesansu, który to kierunek zdaje się $\mathrm{w}$ tym wypadku już przeważać, stoi także ośmioboczny relikwiarz św. Gereona z r. 1533 w katedrze gnié́nieńskiej ${ }^{30}$. Relikwiarz ten, jak i puszka z r. 1522, wyróżnia się dość silnie rozbudowanym cokołem i wzbogaceniem

27 Powiat obornicki, [w:] Katalog zabytków sztuki w Polsce 5: Województwo poznańskie z. 15, opr. I. Galicka, I. Kaczorowska, H. Sygietyńska, Warszawa 1965, s. 17 (ryc. 71).

${ }_{28}$ J. N ow a c ki, Kościót katedralny w Poznaniu, Poznań 1959, s. 496 (ryc. 122); B ochnak, Pagaczewski, Polskie rzemiosło artystyczne.., s. 172-173.

${ }_{29} \mathrm{Bochnak}, \quad \mathrm{Pag}$ a c z ewski, Polskie rzemiosto artystyczne..., s. 179; N owacki, jw., s. $497-498$ (ryc. 121).

${ }^{30} \mathrm{~B}$ ochnak, Pagaczewski, Polskie rzemiosto artystyczne..., s. 173-174; Katedra gnieznieńska..., s. 386; Polkow ski, Katedra gnieznieńska..., s. 241-243 . 
pól wieka kameryzacją. Poszczególne części puszki wydzielono profilowanymi listwami. Na ściankach zaś umieszczono swoiście przetransponowane, wątłe manierystyczne kolumienki. Cokół, ścianki i pola wieka zdobi ryta dekoracja roślinna, nie mająca już nic wspólnego z późnogotyckimi motywami zdobniczymi.

Dokonany przegląd wielkopolskich relikwiarzy z końca w. XV i pierwszej połowy w. XVI wskazuje, że najbardziej były tam rozpowszechnione ośmioboczne puszki o ściankach dekorowanych rytymi przedstawieniami, często scenami z życia świętych, których szczątki zawierały. Zachowane do naszych czasów w Wielkopolsce obiekty nie wyczerpują naturalnie wszystkich tego rodzaju wyrobów. Przykładowo głowa św. Wojciecha przed wykonaniem w r. 1494 nowego złotego relikwiarza znajdowała się, na co dotychczas nie zwrócono uwagi, także $w$ wielobocznej puszce ${ }^{31}$.

3. Wielkopolsko-pomorskie relikwiarze wieloboczne z wieku XVII

Przechodząc do omówienia późniejszych relikwiarzy puszkowych, pochodzących już z wieku XVII, a nawet XVIII, zachowanych na terenie Wielkopolski i na graniczących z nią obszarach, wymienić można dalszych kilka obiektów.

Najwcześniejszym z nich jest relikwiarz z r. 1630 na głowę św. Walentego, ufundowany do kościoła parafialnego w Chełmnie przez Jadwigę z Czarnkowskich Działyńską ${ }^{32}$. Niewątpliwie pod wpływem późnogotyckich piętnasto- i szesnastowiecznych poznańskich relikwiarzy tego typu nadano mu formę ośmiobocznej puszki opatrzonej cokołem i gzymsem w zwieńczeniu ścian, $\mathrm{z}$ podzieloną również na osiem pól kopułową pokrywą z okrągłym wziernikiem pośrodku. Ścianki i pokrywę zdobi ryta, grawerunkowa dekoracja. Na dolnych ściankach relikwiarza wyryto postacie aniołów symbolizujących cnoty, trzymających w rozpostartych dłoniach chusty z napisami oraz herby złożone Nałęcz i Jastrzębiec z literami I. D. S. B. I., a także Ogończyk i Przegonia z literami P. D. S. B. I.; wieko pokrywa powtarzająca się dekoracja roślinna. Jak wskazuje cecha miejska Torunia i cecha imienna, relikwiarz wykonał zapewne znany złotnik toruński Wilhelm de Lassens ${ }^{33}$, którego wyroby zachowały się $\mathrm{w}$ sporej liczbie kościołów prowincjonalnych na terenach pozostających w kręgu oddziaływania tego środowiska. Kończąc należy dodać, że gdyby nie motywy, sposób potraktowania postaci, stojącej zresztą na przeciętnym poziomie dekoracji, chełmski relikwiarz nie różniłby się niczym od późnogotyc-

:1 Katedra gnieźnieńska..., s. 381; P o $1 \mathrm{k}$ o w sk i, Katedra gnieznieńska..., s. 100.

${ }^{32}$ Dawny powiat chetmiński, [w:] Katalog zabytków sztuki w Polsce 11: Dawne województwo bydgoskie z. 4, opr. T. Mroczko, 1975, s. 21 (ryc. 358).

${ }^{53}$ Por. J. Samek, Polskie złotnictwo (w druku). 
kich poznańskich, z których przejęto nie tylko typ, proporcje, ale i technikę zdobienia. Nie jest wykluczone, że któryś z wcześniejszych relikwiarzy wskazany został złotnikowi jako wzór przy wykonaniu zlecenia.

Później powstał ośmioboczny kopułowy relikwiarz św. Klemensa z r. 1651, ufundowany przez Jana Domiechowskiego i proboszcza Piotra z Rogoźna. Związki fundatora oraz porównanie relikwiarza św. Klemensa z puszką pochodzącą z Objezierza, a przechowywaną w Rogoźnie, wskazują, że ta ostatnia posłużyła za wzór dla relikwiarza z r. 1651. Zastosowano tutaj jednak wydatny cokół (podstawa relikwiarza w Rogoźnie zaginęła) wsparty na kulach ujętych w ptasie szpony, ożywiony plastycznymi główkami aniołków. Elementem o gotyckim rodowodzie są poziome fryzy z kroniki ujmujące ścianki. Pola puszki są ozdobione plakietkami z przedstawieniami św. Klemensa, fundatorów, kościoła w Objezierzu i kartuszem odnoszącym się do oględzin relikwiarza dokonanych w r. 1652 przez biskupa poznańskiego Kazimierza Floriana Czartoryskiego.

Nieco inaczej potraktowana została srebrna puszka św. Teodora Męczennika ${ }^{34}$. Puszka ta ofiarowana została przez jezuitę Urbana Ubaldini Zofii Walewskiej, która w r. 1663 przekazała ją kaplicy w Kociszewie. W miejscu kopułki, po której pozostały podziały na pola, zastosowano tutaj płaską pokrywę z wziernikiem; pola mieszczą na przemian trybowane przedstawienia śś. Jana Chrzciciela, Władysława i Zygmunta oraz wzierniki. Cokół, zwieńczenia ścianek, narożniki i wieko pokrywa dekoracja roślinna; na narożnikach $\mathrm{w}$ formie kolumienek. Podstawę stanowią tradycyjne posążki lwów.

W oryginainy sposób potraktowany został także ośmioboczny, tym razem przykryty kopułką z wziernikiem, relikwiarz św. Urszuli z drugiej połowy w. XVII w kościele parafialnym w Wolborzu ${ }^{35}$. Ścianki i wieko pokrywają tutaj duże motywy chrząstkowo-małżowinowe połączone $\mathrm{z}$ roślinnymi, narożniki zaakcentowano rodzajem kandelabrowych kolumienek.

O znacznej popularności wielobocznych relikwiarzy świadczy fakt, że naśladowano je wykonując swoistego rodzaju imitacje. Dowodzi tego relikwiarz z kościoła w Czaczu w dawnym powiecie kościańskim, wykonany w latach sześćdziesiątych w. XVII przez wybitnego złotnika poznańskiego Wojciecha Budzyniewicza ${ }^{36}$. Relikwiarz ten został tak skomponowany, że

${ }^{34}$ Powiat piotrkowski, [w:] Zabytki sztuki w Polsce. Inwentarz topograficzny 4: Województwo tódzkie, Warszawa 1950, s. 112 (ryc. 77). Wysokość $12 \mathrm{~cm}$, średnica podstawy $20,5 \mathrm{~cm}$, średnica nakrywy $17 \mathrm{~cm}$. Przy okazji mależy zaznaczyć, że wymienione relikwiarze, poza złotymi, były z reguły wykonane z pozłacanego srebra.

35 Tamże, s. 318 (ryc. 224). Wysokość $15,5 \mathrm{~cm}$.

s6 A. Waisilkowska, O ztotnikach wyszkolonych $w$ Krakowie a działajacych $w$ Poznaniu $w$ XVII wieku, „Biuletyn Historii Sztuki” 36 (1974) nr 3 s. 352 (ryc. 4). 
chociaż posiada tylko trzy ścianki od przodu i jedną dużą od tyłu, sprawia nieodparte wrażenie, że oglądamy wieloboczne ostensorium. Ścianki, jak to często miało miejsce $\mathrm{w}$ tego rodzaju obiektach, mają podłużne wzierniki; wieko zdobi podtrzymywana przez anioły korona, zaś całość pokrywa bogata dekoracja ornamentem chrząstkowo-małżowinowym z hermami i uskrzydlonymi główkami aniołków.

Jak wynika z powyższego przeglądu, siedemnastowieczne i pochodzące z początku następnego stulecia puszki relikwiarzowe na terenie Wielkopolski i w kręgu jej oddziaływania, silnie nawiązywały do znanych z tego terenu rozwiązań późnogotyckich, przy czym zachowało się ich znacznie mniej niż z czasów ,,jesieni średniowiecza”.

\section{Małopolskie relikwiarze wieloboczne z XVII-XIX wieku}

W inny sposób objawia się żywotność typu kopułowych relikwiarzy wielobocznych na terenie Małopolski. Za najwcześniejsze doń nawiązanie w czasach nowożytnych uważać można ośmioboczny relikwiarz na głowę św. Jacka w kościele dominikanów w Krakowie (ryc. 10), ufundowany przez króla Zygmunta III Wazę ex voto zdobycia Smoleńska w r. $1611^{37}$. $\mathrm{Ma}$ on kształt mniejszej od dotychczas omawianych ośmiobocznej puszki, przykrytej okrągłą kopułką z wziernikiem. Cokół i zwieńczenie na kopułce roboty mosiężnika krakowskiego Franciszka Kopczyńskiego pochodzi z drugiej połowy w. XIX (pierwotnie, jak podają archiwalia, puszka wspierała się na posążkach aniołów). Ścianki relikwiarza zdobią sceny z życia Chrystusa: Ostatnia Wieczerza, Umycie nóg, Chrystus w Ogrojcu, Biczowanie, Cierniem koronowanie, Chrystus przed Piłatem, Upadek pod krzyżem, Ukrzyżowanie. Narożniki akcentują wydatne kolumienki toskańskie, nadto do dekoracji posłużono się motywami roślinnymi, uskrzydlonymi główkami aniołków oraz, jak się wydaje, różnego pochodzenia biżuterią i kameryzacją. W stosunku do relikwiarza św. Jacka wysuwano różne hipotezy. Adam Bochnak w oparciu o wzmiankę w archiwaliach mówiącą o tym, że dzieło jest ,augszpurskiej roboty” doszedł do wniosku, iż relikwiarz zamówiony został w Augsburgu. Andrzej Fischinger wysunął sugestię o zmontowaniu puszki z różnych elementów, dopuszczając zgodnie z tradycją własnoręczny udział króla Zygmunta III Wazy przy jej wykonywaniu. Autor niniejszej rozprawy zwrócił uwagę na fakt, iż

${ }^{37}$ L. Lepszy, S. Tomkowicz, Kraków. Kościót i klasztor OO. Dominikanów, [w:] Zabytki sztuki w Polsce, t. 1, Kraków 1924, s. 55 (ryc. 41); A. B o c hnak, Dwie puszki z herbami Wazów w kolegiacie łowickiej, „Prace Komisji Historii Sztuki" $6(1934 / 5)$ s. 48; J. S a mek, Importy $w$ polskim rzemiośle artystycznym (na przykładzie złotnictwa i jubilerstwa), [w:] O rzemiośle artystycznym $w$ Polsce, Warszawa 1976; Sztuka dworu Wazów w Polsce. Katalog wystawy, Kraków 1976, s. 63 . 
puszkowy, wieloboczny relikwiarz na głowę św. Jacka przedstawiony w rękach anioła na jednym z malowideł z lat 1619-1625 pędzla Tomasza Dolabelli w kaplicy św. Jacka przy kościele dominikanów w Krakowie (ryc. 11), różni się od zachowanego (ma inne podziały poziome oraz posążki przed kolumnami). Zwróciłem także uwagę, że nie wytłumaczony pczostaje fakt ozdobienia relikwiarza scenkami z życia Chrystusa, a nie z życia św. Jacka. Dochodzimy więc do wniosku, że relikwiarz powstał raczej w Krakowie, z zastosowaniem być może augsburskiej roboty plakietek i różnego pochodzenia biżuterii. Niezależnie od ostatecznego ustalenia jego proweniencji należy on do typu wielobocznych relikwiarzy kopułowych.

Niedługo po dominikańskim powstał relikwiarz bł. Salomei ufundowany do kościoła Franciszkanów w r. $1631^{38}$. Niestety zaginął on z początkiem w. XIX w wyniku rekwizycji austriackiej. Sprawiona w tym czasie nowa, skromna puszka jest ośmioboczna z wyraźnie wyodrębnionym cokołem i rodzajem kopulki, co stanowi skromny przekaz informujący o jej pierwotnym wyglądzie.

Znacznie bogaciej potraktowany został srebrny relikwiarz na głowę bł. Szymona z Lipnicy, sprawiony do kościoła Bernardynów w Krakowie w r. $1685^{39}$. Srebrny i pozłacany, ośmioboczny, przykryty kopułką z wziernikiem kontynuuje typ skrystalizowany na terenie Krakowa przez relikwiarz św. Stanisława biskupa z r. 1505. Puszka na głowe bł. Szymona z Lipnicy, idąc za średniowiecznymi relikwiarzami, ma wyodrębniony cokól, wsparty na czterech nóżkach w kształcie kuli. W zwieńczeniu ścianek umieszczono profilowany gzyms, zaśs pola pokrywy dzielą listwy z perełek z gotycyzującą koronką po obu stronach. Na siedmiu ściankach wyobrażono w płaskorzeźbach wyđarzenia z życia bł. Szymona: Bt. Szymon przed kolegium osłarżony o nadużywanio imienia Jezus, Przyjecie do zakonu (?), Próba ognia, Sadzenie dębu, Bt. Szymon przed papieżem, Kazanie, Bz. Szymon wśród chorych; ósma ścianka mieści inskrypcję z datą beatyfikacji świętego, która miała miejsce w r. 1685. W ten sposób powtórzono w relikwiarzu - znaną nam ze średniowiecznych tego rodzaju obiektów - metodę zdobienia ścianek scenami z życia świętego. Narożniki puszlri zaakcentorxane zostały uskrzydlonymi główkami aniołków przechedzącymi w hermy, cokół, górne części ścianel i pola pokrywy zdobi powtarzająca się dekoracja roślinna. Choć jest to dzieło dekoracyjne i interesujace z ilsonograficznego punktu widzenia, poziom roboty złotniczej

3s A. Karwacki, Bt. Salomea za życia i po śmierci. W siedemsetna rocznicę jej urodzin, Kraków 1911, s. 152-153, 190; B ochnak, Pagacze w s i, Polskie rzemiosto artystyczne, s. 175.

39 K. Kantak, J. Szablowski, J. Zarnecki, Kościót $i$ klasztor Bernardynów w Krakowie, Kraków 1938, s. 142-n. (Biblioteka Krakowska 96). Wysokość $26 \mathrm{~cm}$, długość boków $9,5 \mathrm{~cm}$. 
uznać należy za niewysoki, zaś walory scenek figuralnych wynikają raczej z pewnych cech właściwych dla sztuki nieprofesjonalnej aniżeli umiejętności złotnika.

Nieporównanie wyższym poziomem artystycznym wyróżnia się relikwiarz na głowę św. Jana Kantego (ryc. 12) z r. 1695, przechowywany w kolegiacie św. Anny w Krakowie ${ }^{40}$. Jest on, jak informuje napis, dziełem wybitnego krakowskiego złotnika Jana Ceyplera wykonanym według projektu (rysunku) malarza Jerzego Eleutera Siemiginowskiego, przy czym projekty rzeźb miał wykonać Jan Liszkowic. Jest to fundacja profesorów Akademii Krakowskiej, których nazwiska wymienione zostały również na spodniej ściance relikwiarza. Srebrna, złocona puszka na głowę św. Jana Kantego wyróżnia się starannym wykonaniem i bogatą dekoracją. Jest ona ośmioboczna, $\mathrm{z}$ wydatnym cokołem $\mathrm{z}$ postumentami, wsparta na ośmiu nóżkach w kształcie spłaszczonych kul. Ścianki wieńczy rodzaj belkowania, całość zaś - kopułka z okrągłym wziernikiem. Ścianki zdobi osiem płaskorzeźb $\mathrm{z}$ wydatnymi, w płytkim reliefie rozbudowanymi scenami $\mathrm{z}$ życia św. Jana Kantego. Złotnik zobrazował tutaj, zapewne przy współudziale wspomnianego już Siemiginowskiego, najważniejsze wydarzenia z życia świętego: Wykład $w$ Akademii (z widokiem dziedzińca Collegium Maius), Nocne czuwanie Jana na modlitwie w krużgankach Akademii, Oddanie płaszcza ubogiemu, Spotkanie niewiasty lamentującej nad rozbitym dzbanem $z$ mlekiem, Napad zbójców, Modlitwa świętego w czasie pożaru Krakowa, Kazanie, Nawracanie zbójców. Poszczególne scenki odbywają się na tle architektury, a także przyrody, przy czym złotnik dobrze radził sobie $\mathrm{z}$ oddaniem postaci ludzkiej $\mathrm{w}$ skomplikowanym ruchu i z powodzeniem stosował perspektywiczne skróty. Również wysoki poziom artystyczny cechuje osiem postaci kobiecych umieszczonych na postumentach cokołu na tle pilastrów, które akcentują narożniki puszki. Symbolizują one osiem błogosławieństw, odpowiadających cnotom świętego. Wieko relikwiarza zdobi świetnie kuta roślinna dekoracja z motywem tzw. suchego akantu, główki aniołków oraz rozety. Tutaj także, jak i na belkowaniu oraz postumentach złotnik zastosował delikatną kameryzację i różnobarwną emalię. Jest to niewątpliwie najpiękniejszy z zachowanych do naszych czasów siedemnastowiecznych relikwiarzy puszkowych w Polsce.

W sześć lat po wykonaniu relikwiarza na głowę św. Jana Kantego,

40 Kościoty i klasztory śródmieścia 1, [w:] Katalog zabytków sztuki w Polsce 4: Miasto Kraków cz. 2, Warszawa 1971 (kościół św. Anny opracowała T. Ma 1k ow k k-Holcerowa), s. 89 (yc. 820); „Rocznik Muzeum Narodowego w Warszawie" 8 (1964) s. 328-341 (ryc. 15-31); autorka w oparciu o mylnie zinterpretowaną moją informację podaje wykonawców relikwiarza jako wiadomość archiwalną, w rzeczywistości opublikował ją, zapewne według danych archiwalnych, Kołaczkowski. Wysokość $38 \mathrm{~cm}$, szerokość $30 \mathrm{~cm}$. 
w r. 1701 ufundowany został przez księdza Władysława Opackiego do kościoła parafialnego w Kościelcu pod Proszowicami relikwiarz na głowę św. Pauli ${ }^{41}$. Ośmioboczny (ryc. 13), przykryty kopułką zdaje się on nawiązywać przez zastosowanie na narożnikach kolumn o gładkich trzonach do relikwiarza św. Jacka u dominikanów. Znacznie silniejsze więzy łączą go jednak z relikwiarzem św. Jana Kantego, roboty Jana Ceyplera w kościele św. Anny. Tak jak i tam akcentując narożniki podpory mają wyraźne postumenty o profilowanych cokołach i gzymsach. W zbliżony sposób potraktowano również przełamujące się belkowanie, dźwigane przez kolumny (w Krakowie przez pilastry). Podobne sa także podziały kopułki na pola za pomoca motywu tzw. suchego akantu. Skromniejsza jest natomiast dekoracja, wyłącznie roślinna, na którą składają się duże motywy owocowo-kwiatowe uzupełnione w narożnikach liśćmi (na ściankach), który to motyw w nieco innej formie powtórzony został również na polach pokrywy. Cokół ożywiają uskrzydlone główki aniołków i rozety. Warto jeszcze dodać, że cała puszka wspiera się na ośmiu nóżkach w kształcie spłaszczonych kul. Choć relikwiarz św. Pauli stoi na zdecydowanie niższym poziomie artystycznym niż puszka na głowę św. Jana Kantego, liczne podobieństwa w sposobie potraktowania cokołu, belkowania i ornamentu tzw. suchego akantu pozwalają na wysunięcie hipotezy, że kościelecki relikwiarz powstał w kręgu oddziaływania Jana Ceyplera - najprawdopodobniej wykonał go nie sam mistrz, lecz któryś z jego uczniów.

Stopniowe podupadanie złotnictwa krakowskiego, co da się wyraźnie zaobserwować w drugiej połowie XVIII stulecia, zaznaczyło się również w ilości i jakości powstających w Krakowie wielobocznych relikwiarzy. $\mathrm{Z}$ tego okresu możemy na razie wskazać tylko jeden obiekt, mamy tu na myśli relikwiarz śś. Kryspina i Kryspiniana (ryc. 14), ufundowany w r. 1779 przez szewców krakowskich ${ }^{42}$, wykonany $\mathrm{z}$ miedzi, posrebrzany i częściowo złocony. Jest on wprawdzie okrągły, ale w puszce wyraźnie zaznaczono podział ścianki półkolumienkami na sześć pól, opatrzono ją wydatnym cokołem, zaś wieko z sześciolistnym wziernikiem wyodrębnione gzymsem otrzymało podział rodzajem perełek na sześć pól. Na poszczególnych polach ścianki przedstawiono symbole męczenników i narzędzia szewskie. Nadto cokół i gzyms nad półkolumienkami zdobią plastyczne, uskrzydlone główki aniołków, zaś wieko - ten sam motyw ujęty w rokokową dekorację. Robota złotnicza relikwiarza jest dość gruba, w zastosowaniu półkolumienek dopatrywać się można nawiązania do re-

41 Powiat pińczowski, [w:] Katalog zabytków sztuki w Polsce 3: Województwo kieleckie z. 9, opr. K. Kutrzebianka, J. Z. Łoziński, B. Wolff, Warszawa 1961, s. 38.

42 Wysokość $26 \mathrm{~cm}$, średnica $28,5 \mathrm{~cm}$. Por. J. S a me k, Zapomniana wystawa krakowskich zabytkow $i$ pamiatek cechowych, „Krzysztofory” (Zeszyty Naukowe Muzeum Historycznego miasta Krakowa) 6 (1979) s. $79-81$ (il. 3). 
likwiarza św. Jacka czy może św. Jana Kantego. Relikwiarz fundacji cechu szewców, przechowywany w kościele śś. Piotra i Pawła, wyraźnie świadczy o tym, jak dalece obniżył się poziom złotnictwa w dawnej stolicy Polski.

W XIX wieku wykonywano w Krakowie wieloboczne relikwiarze; typ ten, jak się wydaje, odżył w tym okresie, być może był to ostatni etap jego żywotności.

$\mathrm{Na}$ samym początku stulecia, w r. 1810 powstał sześcioboczny relikwiarz św. Doroty w kościele św. Marka w Krakowie (ryc. 15). I tu zastosowano, wzorem wcześniejszych egzemplarzy tego typu, wydatny cokół, przykrywając puszkę rodzajem kopułki z wziernikiem; prostokątne wzierniki umieszczono także we wszystkich ściankach relikwiarza. Szerokie, liściaste fryzy zastosowane na cokole i pokrywie wskazują na przenikanie do złotnictwa krakowskiego motywów klasycystycznych. Drobne ornamenty na narożnikach relikwiarza, wśród których znaleźć można orle skrzydła oraz motywy znane ze znaków rzymskich legionów pozostają w zgodzie $\mathrm{z}$ datą powstania puszki w czasach napoleońskich. Daleka od finezji robota złotnicza jest wykładnikiem ówczesnych możliwości krakowskich mistrzów.

Znacznie bogaciej potraktowany został relikwiarz bł. Bronisławy (ryc. 16), jaki ufundowała w r. 1840 ksieni krakowskich norbertanek Ewa Stobiecka. Wykonał go, jak wskazuje napis na dnie puszki, nie złotnik, lecz brązownik krakowski Franciszek Kausal. Wrócono tutaj do formy ośmiobocznej puszki na podwójnym cokole z kopulastą pokrywką i okrągłym wziernikiem, ze ściankami mieszczącymi również wzierniki (w neogotyckich obramieniach), z umieszczonymi tam półpostaciami świętych. W zwieŕczeniu ścian znajduje się dość wydatny gzyms. Podzielone na pola wieko posiada dekorację roślinną wyraźnie naśladującą podziały wieka relikwiarza na głowę św. Jana Kantego. Uderza tu także dość obficie zastosowana kameryzacja. Relikwiarz w klasztorze norbertanek na Zwierzyńcu, cechujący się poprawnym wykonaniem $\mathrm{z}$ punktu widzenia warsztatowego, informuje c przyjmowaniu przez krakowskich rzemieślników form neogotyckich, przy czym nie rezygnowali oni z nawiązującej do baroku klasycystycznej dekoracji (fryzy roślinne na cokole i wici na pokrywie).

Ostatni i najpóźniejszy znany nam relikwarz tego typu to puszka św. Konstancjusza, przechowywana w kościele śś. Piotra i Pawła w Krakowie ${ }^{43}$. I tu posłużono się forma ośmioboku z wydatnym cokcłem oraz kopułką i czterolistnym wziernikiem. Scianki również mieszcza póltsliście

43 Kościoly i klasztory śródmieścia 2, [w:] Katalog zabytków satuki w Polsce 4: Miasto Kraków, Warszawa 1978 (kościół śś. Piotra i Pawła opracowała I. Rejduch-Samkowa), s. 88 . Wysokość $23,5 \mathrm{~cm}$, średnica $25 \mathrm{~cm}$. 
zamknięte wzierniki, jedyną zaś dekoracją jest umieszczony wokół fryz roślinny. Brak innych motywów i skromne formy puszki utrudniają datowanie - powstała ona zapewne w drugiej połowie XIX stulecia.

\section{IV}

\section{CECHY CHARAKTERYSTYCZNE I PROBLEM GENEZY TYPU POLSKICH RELIKWIARZY KOPUEOWYCH}

Dokonany przegląd upoważnia do sformułowania szeregu uwag określających bliżej typ wielobocznych relikwiarzy kopułowych. Tego rodzaju relikwiarze przeznaczone były wyłącznie na głowy świętych lub partykuły czaszek. Z reguły posiadają one formę ośmiobocznych lub sześciobocznych puszek. Obiekty o dwunastu bokach lub okrąłłe, z zaznaczonymi podziałami na pola należą do rzadkości. Polrrywy tych relikwiarzy otrzymywały formę spłaszczonych, podzielonych na pola kopułek opatrzonych okragłym lub wielolistnym wziernikiem. Płaskie przykrycie posiada tylko relikwiarz św. Teodora w Kociszewie. Ścianki dekorowano w najbogaciej potraktowanych wyrobach scenkami z życia świętych, których relikwie zostały w puszce pomieszczone, postaciami świętych w nawiązaniu do zawartości puszki — w jednym tylko wypadku przedstawione zostały sceny z życia Chrystusa (relikwiarz św. Jacka u dominikanów w Krakowie); zdarzają się też przedstawienia aniołów z inskrypcjami symbolicznymi, wyobrażenia fundatorów lub kościoła, do którego relikwiarz był fundowany, herby ofiarcdawców lub godła katedry, do której puszka należała, oraz napisy fundacyjne, niekiedy wymieniające nazwisko złotnika. W skromniej dekorowanych puszkach ograniczano się do motywów roślinnych czy ornamentalnych. W czasach nowożytnych, w XVII i XVIII stuleciu do stosowanych w późnym gotyku cokołów i gzymsów doszły kolumny i pilastry, przed którymi w wyjątkowo bogatych rozwiąaniach umieszczono pełnoplastyczne posążki. Ze szczegółów warto jeszcze wspomnieć, że jako podstawy dla relikwiarzy stosowano w bogatych fundacjach posążki aniołów (relikwiarz św. Stanisława biskupa i św. Jacka), w skromniejszych - kule, czasem ujęte w ptasie szpony lub splaszczone gałki (o.yginalnym wyjątziem od tych reguł są jabłka zastosowane w puszce siw. Sabiny). Nie zawsze jednak używano, jako podstaw, osobnych eiementów. Co najmniej połowa ze znanych nam relikwiarzy posiada tylko rozbudowany cokół.

Jeśli chodzi o zastosowanie techniki, w Małopolsce posługiwano się dekoracją piastyczną, w Wielkopolsce - grawerunkami; odstępstw od tej reguły znamy niewiele. Obok rytej i plastycznej dekoracji stosowano 
też kameryzację, często bardzo obficie. Miało to miejsce naturalnie w najcenniejszych, wykonanych ze złota relikwiarzach, choć zdarzało się, że i nieco skromniejsze wzbogacano szlachetnymi i półszlachetnymi kamieniami. Ciekawe nawiązanie do tego sposobu dekoracji stanowią, wprawione w relikwiarz św. Barbary sprzed r. 1493 w katedrze gnieźnieńskiej, kamienie przywiezione przez Jakuba Baksice z Ziemi Swiętej. Rzadki przykład posłużenia się, zresztą w niewielkim zakresie barwną emalią stanowi relikwiarz św. Jana Kantego z r. 1695.

Przechodząc do czasu występowania - najwcześniejszy zachowany do dziś obiekt, który reprezentuje omawianą grupę, to relikwiarz św. Floriana z drugiej ćwierci $\mathrm{w}$. XV w katedrze na Wawelu. W świetle archiwaliów mogły jednak istnieć i wcześniejsze obiekty tego typu, nie znamy bowiem daty wykonania relikwiarza św. Wojciecha, który poprzedził puszkę roboty Bartha. Za najpóźniejszy przykład tego typu uznać można relikwiarz św. Konstancjusza w kościele śś. Piotra i Pawła w Krakowie, powstały zapewne $\mathrm{w}$ drugiej połowie w. XIX. Jako czas największego nasilenia typu wskazać należy drugą połowę w. XV i pierwszą połowę XVI stulecia (znamy dwanaście relikwiarzy tego rodzaju) oraz w. XVII i początek w. XVIII ( $\mathrm{z}$ tego okresu zachowało się osiem wielobocznych puszek). W pierwszym etapie rozwoju pod względem ilościowym przodowała Wielkopolska, a właściwie Poznań, w drugim - Kraków. Należy tu zaznaczyć, że siedemnastowieczne puszki ze względu na ich silne związki z późnogotyckimi rozpatrywać można jako swoisty nawrót do „jesieni średniowiecza" ${ }^{44}$.

W sumie udało się zebrać $\mathrm{W}$ obecnym stanie badań blisko trzydzieści interesujących nas relikwiarzy, było ich jednak - że wspomnę cytowane już archiwalia - niewątpliwie więcej. Jeśli chodzi o warsztaty i wykonawców, kopułowe relikwiarze wykonywali najwybitniejsi polscy złotnicy: Jakub Barth, Marcin Marciniec i Jan Ceypler.

Osobne zagadnienie stanowi przeznaczenie wielobocznych ostensoriów. Rzecz szczególna i charakterystyczna - otrzymali je niemal wszyscy polscy święci i błogosławieni: Wojciech, Stanisław biskup, Jacek, Jan Kanty, Szymon z Lipnicy i Bronisława. Wykonywano je również dla świẹtych otaczanych w Polsce szczególnym kultem lub cieszących się kultem lokalnym: Floriana, Barbary, Urszuli, Szczepana, Wita, Otylii, Sabiny, Klemensa, wreszcie Kryspina i Kryspiniana. Relikwiarze te były i są używane do specjalnych celów - wystawiane na ołtarzach i noszone w procesjach w święta patronów, których relikwie zawierają. Świadczyć o tym może choćby corocznie powtarzany ceremoniał przenoszenia re-

${ }^{44} \mathrm{~S}$ a mek, Nawrót do gotyku..., s. 45. 
likwii św. Stanisława biskupa dnia 8 maja z katedry wawelskiej na Skałkę.

Osobną sprawą jest zagadnienie czasu i miejsca powstania typu. Jak dotąd wysunięto właściwie jedną hipotezę - mianowicie w oparciu o dość problematyczne wiązanie relikwiarza św. Floriana z osobą złotnika Marcina Goldsmeda (1404-1425), usiłowano dowieść, że interesujący nas typ wywodzi się z ruskich, a nawet bizantyńskich wzorów ${ }^{45}$. Hipoteza ta, w odniesieniu do ruskiej genezy wzoru, jak wykazały moje rozmowy przeprowadzone ze specjalistami w Moskwie, nie znalazła potwierdzenia. Równocześnie jednak, jak wielokrotnie wskazywał Adam Bochnak ${ }^{46}$, co przyznawał również Bolesław Przybyszewski, w żadnym z europejskich środowisk złotniczych nie da się wskazać takiej ilości wielobocznych relikwiarzy kopułowych, co w środowisku poznańskim i krakowskim. W tej sytuacji sprawę genezy typu należałoby pozostawić otwartą, podtrzymując jednocześnie hipotezę, że powstał on, a już z całą pewnością rozwinął się i skrystalizował w Polsce, raczej w środowisku poznańskim, nie krakowskim, może pod wpływem nieznanego, obcego archetypu ${ }^{47}$.

Jakież miejsce zajmuje w tym długim przeglądzie relikwiarz św. Stanisława biskupa roboty Marcina Marcińca z r. 1505? Niewątpliwie należy on do najwyższych osiągnięć w obrębie prezentowanego typu. Można nawet powiedzieć, że jest najbogaciej potraktowanym i wyróżniającym się obok relikwiarza św. Jana Kantego oraz puszek św. Wojciecha w Gnieźnie i św. Urszuli w Szamotułach — najwyższym poziomem artystycznym. Bez przesady wolno powiedzieć, iż jest to klejnot krakowskiego złotnictwa, najwyższe zachowane do naszych czasów osiągnięcie tutejszych mistrzów.

W sztuce polskiej, jako swoisty fenomen, rozpowszechniły się za wzorem mauzoleum Zygmuntów przy katedrze na Wawelu czworoboczne, czasem wieloboczne lub okrągłe kopułowe kaplice grobowe, które wznoszono aż do w. XVIII włącznie. Do tego to zjawiska przyrównać można żyjący od w. XV do XIX typ kopułowych relikwiarzy wielobocznych, tym bardziej że bliska była sobie w obu wypadkach symbolika: i kaplice, i re-

45 Przybyszewski, jw., s. 54 nn.

46 B ochnak, Barth Jakub..., s. $311-312$.

$47 \mathrm{Na}$ powstanie i rozwój typu relikwiarzy wielobocznych w Polsce mogły oddziałać podobne obiekty lub wieloboczne relikwiarze wsparte na wyraźnie wykształconej stopie, spotykane na terenie Europy zachodniej. Mamy tu na myśli przykładowo relikwiarz św. Regnoberta w kościele św. Piotra w Varzy z w. XIII i relikwiarz na głowę św. Zuzanny z kościoła św. Gerwazego w Avranches z końca w. XIII lub początków XIV stulecia (por. Les tresors des eglises de France, Paris 1965, $\mathrm{nr}$ kat. 803 na s. 427-428, il. 98, i nr kat. 230 na s. 119, il. 147), a także z późniejszych już zabytków - np. relikwiarz św. Jadwigi z 1553 r. z kościoła św. Bartłomieja w Trzebnicy. 
likwiarze symbolizowały swą formą byt ziemski i doskonałość wieczną zgodnie z chrześcijańską dewizą: „Kto się pod tymi sklepieniami znajduje, widzi siebie w niebiosach" ${ }^{48}$.

\author{
DAS RELIQUTAR DES HL. STANISLAW AUS DEM JAHRE 1505 \\ UND ANDERE RELIQUIENBÜCHSEN DIESES TYPS IN POLEN
}

\title{
Zus a m m e f a s ung
}

Mit polygonalen Kuppelreliquiaren in Polen zur Aufbewahrung der Häupter der Heiligen befaßten sich bisher nur Adam Bochnak und Julian Pagaczewski sowie der Autor der vorliegenden Arbeit. Infolge der von ersten der erwätnten Autoren angestellten Beobachtungen wurde festgestellt, daß diesen Typ von Reliquiar als frühestes das Reliquiar des hl. Florian (ursprünglich des hl. Stanislaw), gestiftet von Königin Sophie, der Gattin des Wladislaw II Jagello, repräsentiert, das in der Schatzkammer der Krakauer Kathedrale aufbewahrt wird. Adam Bochnak bemerkte außerdem, daß diesen Typ von Reliquiar einige zehn Exemplare repräsentieren.

Zweifellos das hervorragendste Beispiel dieses Typs ist das, das Haupthema des vorliegenden Traktats bildende oktogonale Reliquiar für das Haupt des hl. Stanislaw, des Bischofs und Märtyrers, angefertigt aus Gold von gutem Gehalt unter Anwendung von Guß-, Treib- und Graviertechniken, außerordentlich sorgfältig ziseliert und mit Edelsteinen und Perlen versetzt. Im Jahre 1505 wurde dieses Reliquiar der Krakauer Kathedrale von Königin Elisabeth aus dem Hause Habsburg, der Witwe des Königs Kasimir IV Jagello, vom Fonds ihrer Söhne Johannes Olbracht und Kardinal Friedrich Jagello auf Amregung des Krakauer Bischofs Johannes Konarski gestiftet. Verziert wurde es mit reliefartig ausgeführten bedeutenden Szenen aus dem Leben, oder besser gesagt dem Märtyrertum des Heiligen. Es sind dies: Der Kauf eines Dorfs, Die Erweckung des Ritters Peter, Die Zeugung vor dem König, Die Tötung des Heiligen, Das Zerhauen des Leichnams des Märtyrers, Die Bewachung des Leichnams durch Adler, Das Begräbnis, Die Kanonisierung in Assisi. Das Reliquir zeichnet sich durch hervorragende Goldschmiedearbeit aus und ist, was hervorgehoben werden muß, das prächtigste, hinsichitlich des Materials und der Komposition, Werk der spätgotischen Krakauer Goldschmiedekunst.

Angefertigt wurde dieses hervorrgende Werk - wie eine Aufschrift informiert von dem Goldschmied Martin Marciniec. Über diesen Meister ist vieles bekannt. Er stammte aus einer wohlhabenden Krakauer Bürgeríamilie. Im Jahre 1486 wirkte er bereits als Meister und hatte Lehrlinge, woraus sich schließen läßt, daß er kurz nach der ersten Hälfte des X.V Jhs geboren wurde. Zu Beginn des XVI Jhs wird erwähnt, daß Narciniec für Jakob Sancygniowski, den Starosten von Busko, arbei-

48 Por. H. S e d $1 \mathrm{~m}$ a y r, Die Entstehung der Kathedrale, Zürich 1950, s. 47-50, 136. Dodać tu należy, że relikwiarze puszkowe, powstałe w czasach nowożytnych, przywodzą na myśl niewielkie tempietta lub podobne do nich rozwiązania (np. świątyńka w cyborium Padovana w kościele Mariackim Krakowie); relacje te są szczególnie wyraźne w odniesieniu do relikwiarza św. Jacka. 
tete, auch ist bekannt, daß er in den Jahren 1493-1503 Bestellungen des Kardinals Friedrich Jagiello ausführte. Seit 1502 blieb er in Diensten des Kronprinzen und später Königs Sigismund I. Im Jahre 1513 wurde er zum Stadtrat gewählt. Er starb in Krakau am 27. März 1518.

Die Arbeiten Meister Martins sind vor allem aus Archivalien bekannt, jedoch auf Grund der Tatsache, daß er mit Kardinal Friedrich Jagello verbunden war und der Ähnlichkeiten, vorwiegend im Bereich der Ausschmückung, auf dem Reliquiar des hl. Stanisla: des Bischofs aus dem Jahre 1505, brachten Adam Bochnak und Julian Pagaczewski mit der Person des Marciniec weitere Werke in Verbindung, $u$. zw. das sogen. größere, der Gnesener Kathedrale gestiftete Kreuz aus den Jahren 1493-1503 sowie das zu jener Zeit hergestellte Zepter, das der Krakauer Akademie, ähnlich wie auch das Kreuz, von Kardinal Fniedrich zum Geschenk gemacht wurde, und schließlich den reich geschmückten Kelch, der in der Schatzkammer der Pferrkirche in Wieliczka aufbewahrt wird. Es sind dies alles natürlich hipothetische Beifüngen. Das erwähnte Reliquiar war ganz gewiß das prächtigste Werk des Goldschmieds, und der Meister selbst kann als der bedeutendste polnische Goldschmied der Spätgotik gelten.

Um nochmals auf das Problem der polygonalen Kuppelreliquiare in Polen zurückzukommen, muß festgestellt werden, daß der Autor die zu Anfang erẅ̈hnten Forschungen erheblich erweiterte, indem er 4 Grouppen polygonaler Reliquiare aussonderte:

1) Die kleinpolnische Gruppe aus dem XV bis XVI Jh. repräsentieren: das anfangs erwähnte Reliquiar für das Haupt des hl. Florian aus der Wawel-Kathedrale; das bescheidene Reliquiar der hl. Ursula aus der Mitte des XV Jhs oder möglicherweise schon aus der zweiten Hälfte dieses Jahrhunderts aus der Stephanskirche in Krakau; das den Gegenstand der vorliegenden Arbeit darstellende Reliquiar, das Werk des Martin Marciniec; die während des II. Weltkriegs aus der Kirche in Stopnica verlorengegangene, von Boruta gestiftete Büchse, die mit ausgezeichneten Gravüren geschmückt war und wahrscheinlich aus dem zweiten Jahrzehnt des XVI Jhs stammte; schließlich das als aus Nürnberg eingeführt betrachtete, und deshalb nur teilweise zu der besprochenen Gruppe zählende runde, mit Perlmutt verzierte Reliquiar für das Haupt des hl. Stefan, das in der neuen Kirche unter diesem Patron aufbewahrt wird, ebenfalls in Krakau, und das aus dem zweiten Viertal des XVI Jins datiert.

2) Zur Gruppe großpolnischer Kuppelreliquiare zählen: das sich in der Gnesener Kathedrale befindliche Reliquiar der hl. Ursula, im Jahre 1481 von Benedikt aus Lopienna gestiftet, mit plastischen Szenen und Gravüren verziert (möglicherweise nicht einheitlich); das aus den Jahren 1484-1493 stammende Reliquiar der hl. Barbara aus der Stiftung des Jakob aus Boksica, ebenfalls aufberwahrt in Gnesen und verziert vorwiegend mit plastischer Ausschmückung; das reich geschmückte, goldene und mit Edelsteinen verzierte Reliquiar des hl. Adalbert (vermißt), das autorisierte Werk des Posener Goldschmieds Jakob Barth aus dem Jahre 1494, der Gnesener Kathedrale gestiftet; die mit Gravüren verzierte Büchse der hl. Ottilie aus dem Jahre 1496 in dem früheren Kollegiat in Szamotuły; das aus Objezierze stammende und sich in der Pfarrkirche in Rogoźno befindliche Reliquiar, datiert aus der ersten Hälfte des XVI Jhs; die mit der Werkstatt des Posener Goldschmieds Peter Gelhor verbundene, in der Posener Kathedrale aufbewahrte Büchse der hl. Sabine aus dem Jahre 1510, ebenfalls mit Gravüren geschmückt; die sich dort befindliche Büchse des hl. Jokundinus aus dem Jahre 1522; schlieBlich das Reliquiar des hl. Gereon aus dem Jahre 1533 in der Gnesener Kathedrale. 
3) Die großpolnisch-pommerische Gruppe aus dem XVII Jh. repräsentieren: das im Jahre 1630 der Pfarrkirche in Chełmno gestiftete Reliquiar des hl. Valentin, das unter dem Einfluß der spätgotischen Lösungen bleibende Werk des Thorner Goldschmieds Wilhelm de Lassens; das Reliquiar des hl. Clemens, das sich in Rogoźno befindet und der dortigen Büchse aus Objezierze nachgebildet ist, datiert aus dem Jahre 1651; die Büchse des hl. Theodor des Märtyrers, 1663 der Kapelle in Kociszewo gestiftet; das Reliquiar der hl. Unsula aus der zweiten Hälfte des XVII Jhs in der Pfarrkirche in Wolborz; das den Eindruck eines polygonalen ostensorium nachahmende Reliquiar aus der Kirche in Czacz, das Werk des hervorrgenden Posener Goldschmieds Adalbert Budzyniewicz aus den 60er Jahren des XVII Jhs.

4) Die kleinpolnische Gruppe (XVII-XIX Jh.) wird vor allem durch folgende Objekte vertreten: das Reliquiar für das Haupt des hl. Hyazinth aus der Stiftung König Sigismund III. in der Dominikaner-Kirche in Krakau (ein noch nicht ausreichend untersuchtes Werk - möglicherweise Augsburger Herkunft), gestiftet ex voto der Einnahme von Smolensk im Jahre 1611; die Büchse der sel. Salomea, gestiftet im Jahre 1631 für die Franziskaner-Kirche (vermißt zu Beginn des XIX Jh.s); das ebenfalls in Krakau in der Bernhardiner-Kirche aufbewahrte Reliquiar für das Haupt des sel. Simon aus Lipnica aus dem Jahre 1685; das hervorragende Werk des Krakauer Goldschmieds Johannes Ceypler - das Reliquiar für das Haupt des hl. Johannes de Cracovia aus dem Jahre 1695, aufbewahrt im früheren Kollegiat der hl. Amna in Krakau; das im Bereich dieses zuletzt erwähnten Werks verbleibende Reliquiar der hl. Paula, gestiftet im Jahre 1701 der Pfarrkirche in Kościelec bei Proszowice; das von den Krakauer Schuhmachern gestiftete Reliquiar der hl. Krispin und Krispinian aus dem Jahre 1779 in der Peter-und-Paul-Kirche in Krakau; und schließlich die Werke aus dem XIX Jh.: die Büchse der hl. Dorothea aus dem Jahre 1810 in der Krakauer Markus-Kirche, das Reliquiar der sel. Bronislawa aus dem Jahre 1840 bei den Krakauer Norbertanerinnen im Stadtviertel Zwierzyniec, das Werk des Bronzegießers Franz Kausal, und das späteste uns bekannte Reliquiar dieses Typs. die Büchse des hl. Konstantin aus der zweiten Hälfte des XIX Jhs, die in der Krakauer Peter-und-Paul-Kirche aufbewahrt wird.

Dieser Überblick erlaubt die Charakterisierung des Types der polnischen Kuppelreliquiare. Diese Büchsen, die allgemein für die Häupter der Heiligen bestimmt sind, zeichnen sich meist durch okto- oder polykonale Form aus, bedeckt mit Kuppeln mit einer Schauöffnung in der Mitte, die Wände sind verschiedenartig verziert: angefangen mit bildlichen Szenen bis zu Verzierungsmotiven. In der Neuzeit wurden sie durch Säulen, Pilaster und Statuetten bereichert, besaßen auch verschiedene Arten von Sockel (Engelchenstatuetten, Kugeln oder ausgebaute Sockel). Verziert waren sie verschieden, in Kleinpolen meist plastisch, in Großpolen mit Gravüren, häufig neben gestochener und plastischer Ausschmückung wurden sie mit Edelsteinen verziert, manchmal sehr reich.

Ein gesondertes Problem stellen Zeit und Ort des Entstechens des Typs dar, der als eine Ausnahmeerscheinung in der europäischen Kunst gilt, vielleicht gestaltete er sich in Polen, eher in posener Kreisen, nicht in Krakau, aller Wahrscheinlichkeit nach unter dem Einfluß eines näher nicht bekannten Urtyps.

Das besprochene Reliquiar des hl. Stanislaw des Bischofs, das Werk des Martin Marciniec, zählt unzweifelhaft zu den höchsten Errungenschaften innerhalb des dargestellten Typs. Ohne Ubertreibung darf gesagt werden, daß dies ein Kleinot der Krakauer Goldschmiedekunst ist, die größte bis in unsere Zeit erhalten gebliebene Errungenschaft der hiesigen Meister. 